This item was submitted to Loughborough's Research Repository by the author.

Items in Figshare are protected by copyright, with all rights reserved, unless otherwise indicated.

\title{
Candidate effects on election outcomes: Political skill, campaign efficacy, and intentions in a British general election
}

\author{
PLEASE CITE THE PUBLISHED VERSION
}

https://doi.org/10.1111/apps.12292

\section{PUBLISHER}

Wiley

\section{VERSION}

AM (Accepted Manuscript)

\section{PUBLISHER STATEMENT}

This is the peer reviewed version of the following article: Silvester, J. ...et al. (2020). Candidate effects on election outcomes: Political skill, campaign efficacy, and intentions in a British general election. Applied Psychology: an international review. 70(4), pp. 1628-1668. Doi: 10.1111/apps.12292, which has been published in final form at https://doi.org/10.1111/apps.12292. This article may be used for non-commercial purposes in accordance with Wiley Terms and Conditions for Use of Self-Archived Versions

\section{LICENCE}

CC BY-NC-ND 4.0

\section{REPOSITORY RECORD}

Silvester, Joanne, Madeleine Wyatt, B Parker Ellen, and Gerald R Ferris. 2020. "Candidate Effects on Election Outcomes: Political Skill, Campaign Efficacy, and Intentions in a British General Election”. Loughborough University. https://hdl.handle.net/2134/13200185.v1. 
Running head: POLITICAL SKILL, CANDIDATES, ELECTION

Candidate Effects on Election Outcomes:

Political Skill, Campaign Efficacy, and Intentions in a British General Election

\author{
Jo Silvester \\ School of Business and Economics, Loughborough University, \\ Loughborough, LE11 3TU, U.K. \\ j.silvester@1boro.ac.uk
}

Madeleine Wyatt

Kent Business School, University of Kent, Canterbury, Kent, CT2 7NZ, U.K.

m.wyatt@kent.ac.uk

B. Parker Ellen III

D'Amore-McKim School of Business, Northeastern University, 112 Hayden Hall, 360 Huntington Avenue, Boston, MA, 02115-5000, U.S.A. p.ellen@northeastern.edu

\author{
Gerald R. Ferris \\ Florida State University College of Business, \\ 821 Academic Way, Tallahassee, Florida 32306-1110, U.S.A. \\ gferris@business.fsu.edu
}

This article has been accepted for publication and undergone full peer review but has not been through the copyediting, typesetting, pagination and proofreading process, which may lead to differences between this version and the Version of Record. Please cite this article as doi: $\underline{10.1111 / \text { apps. } 12292}$

This article is protected by copyright. All rights reserved 
*Correspondence concerning this manuscript should be addressed to: Joanne Silvester, School of Business and Economics, Loughborough University, Loughborough LE11 3TU, United Kingdom. E-mail: j.silvester@1boro.ac.uk 
PROF. JO SILVESTER (Orcid ID : 0000-0002-2769-4722)

DR. B. PARKER ELLEN III (Orcid ID : 0000-0002-5114-7593)

Article type : Original Article

\begin{abstract}
Integrating Social/Political Influence Theory with the Theory of Planned Behavior, we argue that personal resources (i.e., political skill, self-efficacy) enable political candidates to form more ambitious campaign intentions, and thus perform better in elections. We tested this model with a sample of political candidates $(N=225)$ campaigning in a British general election. Three months before polling day, candidates provided self-ratings of political skill, domain-specific self-efficacy (i.e., campaign efficacy), and personal campaign intentions during the campaign period. Our results demonstrated that, political skill was positively related to campaign efficacy, and intentions, via campaign efficacy. We also found a significant indirect effect for political skill on electoral performance (i.e., percentage of the vote), through campaign efficacy and intentions. Implications of our results for understanding candidate effects in campaigns and future research are discussed.
\end{abstract}

Keywords: candidate effects, political skill, election, campaign efficacy, intentions, votes

This article is protected by copyright. All rights reserved 


\section{Candidate Effects on Election Outcomes:}

\section{Political Skill, Campaign Efficacy, and Intentions in a British General Election}

Despite longstanding academic and public interest in individual characteristics associated with political success (e.g., Jost \& Sidanius, 2004; Mondak, 2010; Winter, 1998), very few studies have examined how psychological characteristics, self-reported by candidates ahead of political campaigns, contribute to their subsequent electoral performance (Sheafer \& Tzionit, 2006; Stevens et al. 2019). These 'candidate effects' (i.e., also known as the 'personal vote' or the part of a legislator's vote based on his or her individual characteristics or record: Cain, Ferejohn, \& Fiorina, 2013; Shugat, Valdini, \& Suominen, 2005), are difficult to investigate, because political candidates are a 'hard to reach' population for researchers. This is particularly true at the beginning of their campaigns (Glad, 2002; Simonton, 1998).

Our research addresses this notable gap in existing research by examining how the self-reported personal resources (i.e., political skill and self-efficacy) of political candidates relate to their campaign intentions and subsequent performance in a national election. In doing so, we theorize and test a model of intrapsychic processes that drive intentions and performance, which integrates Social/Political Influence Theory in organizations (Ferris, Treadway, Perrewé, Brouer, Douglas, \& Lux, 2007) and the Theory of Planned Behavior (Azjen, 1987, 1991). We argue that political skill instils individuals with confidence (i.e., efficacy) that their personal campaign efforts will be successful, and motivates them to select contextually appropriate strategies, or intentions, that subsequently predict performance.

We examine these claims using self-report data provided by political candidates just prior to beginning their campaign in a British general election. Although the political skill construct derives from management research, we argue that candidates campaigning to be elected as Members of Parliament (MPs) represent a particularly apt group for investigating our claims for three reasons. First, it is reasonable to expect that political skill should be relevant for different types of work roles and settings (Munyon, Summers, Thompson, \& Ferris, 2015), including elected and non-elected roles within legislatures (Silvester, 2008; Wyatt \& Silvester, 2018).

Second, scholars have argued for the increased importance of political skill in what have been referred to as enterprising job contexts (Blickle, John et al., 2012). These contexts are noted for extensive interpersonal interactions requiring the ability to connect with diverse groups of people across a variety of situations and perceive others' needs, often in order to persuade them and gain their support. These are all hallmarks of political campaigning. 
Third, in parliamentary systems of government, such as in Britain, national elections involve individual candidates from all political parties campaigning simultaneously over a fixed period to win a seat in parliament in a 'first-past-the-post' election (Electoral Commission, 2019). This provides a rare opportunity to examine the intrapsychic processes linking political skill, efficacy beliefs, intentions, and performance in a semi-controlled field study.

In our study, 225 parliamentary candidates from the same British political party completed an online questionnaire assessing their political skill, campaign efficacy, and personal campaign intentions just prior to a general election campaign (i.e., three months before polling day). The objective performance of each candidate was then measured using the percentage of votes they achieved in the constituency ${ }^{1}$ in the 2010 general election. To better isolate the effects of these variables, we controlled for each candidate's gender, age, facial appearance, prior campaign experience, incumbency, type of seat (i.e., likelihood of winning the seat as evaluated by the party), prior electoral performance of the party in that seat, and the local economic context.

The present study makes two primary contributions to the literature. First, by integrating theories of social/political influence and planned behavior, we introduce domainspecific self-efficacy and intentions as constructs that elucidate the relationship between political skill and objective performance outcomes. Secondly, although researchers have long argued for relationships between psychological constructs and the performance of political elites (e.g., Simonton, 1988; Winter, 1998), as far as we are aware, this is the first study to investigate candidates' self-rated psychological characteristics and intentions, just ahead of a national election, and their subsequent electoral performance. As such, this unique sample allows us to demonstrate the relevance of organizational psychological factors like political skill and self-efficacy in the context of elections and governmental politics, and to contribute to extant political science research on candidate effects.

\section{Research Context: Political Campaigns}

Elections are the primary mechanism for leadership emergence in democratic governments, where candidates from different political parties campaign over the same period in order to win more votes than other candidates, thereby earning the right to represent a constituency in government. Although elections are not unique to politics (i.e., senior leaders in many professional service firms are elected by their peers: Empson, 2017), national

\footnotetext{
${ }^{1}$ Also known as a 'seat' in the U.K. or a 'district' in other national settings.
} 
elections impact the lives of millions, and therefore, receive enormous public attention and engagement. Thus, unsurprisingly, efforts to identify individual characteristics that can influence political performance (i.e., candidate effects) have been an important focus for researchers, both in political science (e.g., Best, 2011; Gerber, Huber, Doherty, \& Dowling, 2011; Mondak, 2010; Pattie, Hartman, \& Johnston, 2019) and psychology (e.g., Caprara \& Zimbardo, 2004; Jost \& Sidanius, 2004).

Extant research suggests that the performance of elected officials is influenced by multiple individual characteristics, including personality (Dietrich, Lasley, Mondak, Remmel, \& Turner, 2012; Mondak \& Halperin, 2008; Mondak, Hibbing, Canache, Seligson, \& Anderson, 2010; Rubenzer, Faschingbauer, \& Ones, 2000; Silvester, Wyatt, \& Randall, 2014), motivation (Winter, 1987, 1998), intelligence (Simonton, 2006), and cognitive style (Tetlock, 1984). Campaign performance also has been associated with candidate characteristics including, occupation (Stevens et al., 2019), gender (Cowley \& Campbell, 2011), political experience (Krebs, 2001; Shugart et al., 2005; Tavits, 2010), appearance (Antonakis \& Eubanks, 2017; Jacquart \& Antonakis, 2015), personality (Nai, 2019; Nai \& Maier, 2018), ideology and values (Joly, Hofmans, \& Loewen, 2018; Schumacher \& Zettler, 2019), and communication (Sheafer, 2008; Sheafer \& Tzionit, 2006).

However, politicians and political candidates are a 'hard-to-reach' population for researchers to study (Caprara \& Silvester, 2018; Simonton, 1998). Consequently, most research has relied on 'at-a-distance' methods to infer individual characteristics and their relationship with political performance. These include aggregated observations and ratings of personality provided by experts and members of the public (Deluga, 2001; Nai 2019; Nai \& Maier, 2018; Rice, Remmell, \& Mondak, 2020; Rubenzer et al., 2000; Visser, Book, \& Volk, 2017; Winter, 1987, 1998), content analysis of political speeches and interviews (Ramey, Klingler \& Hollibaugh, 2016), experiments (Karpowitz, Monson, \& Preece, 2017) and, more recently, automated textual analysis of political communication in debates and Twitter feeds (Baur et al., 2016; Ramey et al., 2016).

Notably, few studies have captured self-report data from legislators in office (c.f., Caprara, Barbaranelli, Consiglio, Picconi, \& Zimbardo, 2003; Caprara, Francescato, Mebane, Sorace, \& Vecchione, 2010; Dietrich et al., 2012; Hanania, 2017), or from candidates at the beginning of their campaigns (Costantini \& Craik, 1980; Silvester \& Dykes, 2007; Wyatt \& Silvester, 2018). Therefore, very little is known about how candidate attributes influence campaign activities and election performance. Further, no study (i.e., to our knowledge) has investigated self-report data on such aspects (e.g., political skill, efficacy, and intentions) 
from political candidates just before a political campaign, to examine their relationships with performance in a national election in a semi-controlled study.

Our research takes place in the context of a parliamentary system of governance, which has certain advantages over a presidential system in terms of research design. For example, when a general election is called, parliament is dissolved and candidates from all political parties begin campaigning at the same time, for a fixed period (i.e., 25 days), governed by strict rules on campaign funding limits (i.e., the equivalent of approximately $\$ 13,500$ in the 2010 general election), and time allowed on national media, in an attempt to equalize opportunities for candidates from small and large political parties (Electoral Commission, 2019). As a result, British candidates, and those in other parliamentary styles of government (i.e., as compared to those in the U.S.), are often more reliant on their own efforts to mobilise activists locally ${ }^{2}$ and engage with constituents during the election period, both to recruit activists and persuade constituents to vote for them (Mondak, 1995; Whitely \& Seyd, 1994).

As with candidate effects, extensive political science research has investigated what factors contribute to 'campaign effects' (i.e., campaign activities that deliver votes, c.f. Greene, 2020). Studies also have shown that in British general elections, constituency-led campaign activities yield electoral dividends (Pattie et al., 2019), and contribute significantly to the share of votes achieved by individual candidates (Clarke, Sanders, Stewart, \& Whitely, 2009; Gerber \& Green, 2000). In the 2010 general election, the British Election Study found that more than a third of voters surveyed (i.e., 37\%) said they had made their decision about how to vote during the campaign period (Fisher, Cutts, \& Fieldhouse, 2011). However, to our knowledge, no study has investigated candidates' self-reported characteristics and personal intentions ahead of the start of their campaign in order to examine how candidate effects, specifically political skill, campaign efficacy, and intentions, may influence electoral performance.

\section{Theoretical Foundations and Hypotheses}

Political skill was introduced to the organizational sciences over three decades ago (Mintzberg, 1983; Pfeffer, 1981), and now is widely recognized as an important determinant of success at work (Ferris, Ellen, McAllister, \& Maher, 2019). Described as a social effectiveness construct that enables individuals to interpret social cues, situationally adjust and adapt their behavior, and present themselves as sincere in interpersonal interactions

\footnotetext{
${ }^{2}$ Although responsibility for the national campaign rests with the party centrally, candidates are responsible for running the local campaign in their constituency.
}

This article is protected by copyright. All rights reserved 
(Ferris, Hochwarter, Douglas, Blass, Kolodinsky, \& Treadway, 2002; Treadway, Hochwarter, Kacmar, \& Ferris, 2005), political skill has been defined as "the ability to effectively understand others at work, and to use that knowledge to influence others to act in ways that enhance one's personal and/or organizational objectives" (Ferris et al., 2005, p. 127). A higher-order construct, political skill is comprised of four facets: social astuteness, networking ability, interpersonal influence, and apparent sincerity (Ferris et al., 2005; Ferris et al., 2007), all of which are relevant to political campaigning.

In recent years, a number of primary studies (e.g., Blickle, Ferris, Munyon, Momm, Zettler, Schneider, \& Buckley, 2011) and two meta-analyses (Bing, Davidson, Minor, Novicevic, \& Frink, 2011; Munyon et al., 2015) have reported that political skill demonstrates a positive relationship with individual performance. However, until recently, research on the mechanisms that link political skill and performance has been lacking (Ferris, Treadway, Brouer \& Munyon, 2012; Grosser et al., 2018; Kimura, 2015).

Additionally, although a few studies have begun to examine political skill's relevance for performance in political leadership roles, such as employees' representatives in the workplace (Blickle, Oerder, \& Summers, 2010) and in local and regional government (Silvester et al., 2014), most studies have focused on its relationships in more traditional work settings (e.g., Zettler \& Lang, 2015).

Social/political influence theory. To clarify how political skill operates to affect workplace performance, Ferris et al. (2007) proposed a meta-theoretical framework of social/political influence (which was extended by Munyon et al., 2015) that outlines three process categories: intrapsychic, behavioral, and interpersonal. Most research has focused on either behavioral processes, examining how political skill influences situational responses and individual actions, such as citizenship behavior, coalition building, and negotiation at work (Munyon et al., 2015), or on interpersonal processes, such as the effect of political skill on group and organizational processes, through mentoring to improve performance (Blass, Brouer, Perrewé, \& Ferris, 2007), and influencing others to secure resources or complete tasks (Blickle, Schneider, Liu, \& Ferris, 2011; Kolodinsky, Treadway, \& Ferris, 2007).

However, in the present study, we focus on intrapsychic processes, which relate to how individuals view their own personal resources and form goals. According to Ferris et al. (2007), politically skilled individuals are more likely to have positive experiences in the workplace, and therefore, evaluate themselves more favorably. Yet, given the comparative rarity of research examining factors that link intrapsychic aspects of political skill to performance, exploring this link is important, because the argument represents a core tenant 
of social/political influence theory (Ferris et al., 2007; Frieder, Ferris, Perrewé, Wihler, \& Brooks, 2019; Munyon et al., 2015).

Specifically, politically skilled individuals monitor and reflect on their personal resources (including their motivation, goals, and abilities), accurately interpret social cues and contexts, and thus identify appropriate influence strategies (McAllister, Ellen, \& Ferris, 2018) to mobilize action at individual, group, and organizational levels. This, in turn translates into heightened work performance (Ferris et al., 2007; Munyon et al., 2015). For insight into how two constructs (i.e., domain-specific self-efficacy and intentions) can explain the intrapsychic political skill-performance relationship, we turn to the Theory of Planned Behavior (Ajzen, 1991).

Theory of planned behavior. The Theory of Planned Behavior (Ajzen, 1987; 1991) was developed to explain the link between cognition and action, and it proposes that the crucial mediator of this relationship is an individual's behavioral intentions. These intentions relate to the motivation and effort that individuals are willing to exert to achieve their desired level of performance, and which reflect the subjective probability that an individual will perform a specific behavior.

Ajzen (1991) suggested that behavioral intentions are driven by three factors: attitude towards the behavior, which refers to whether individuals expect their behavior to achieve particular outcomes and whether these are desirable; subjective norms, which relate to perceived pressure to perform the behavior, based on what influential people known by the individuals think about their intentions, and; perceived behavioral control, which refers to individuals' efficacy beliefs or perceptions of their ability to perform a behavior, taking into account past experiences and perceived personal and situational barriers (e.g., resources, and opportunities).

The Theory of Planned Behavior has been applied in a range of contexts, most notably to predict and identify interventions for health behavior, such as smoking cessation (e.g., Harakeh, Scholte, Vermulst, de Vries, \& Engels, 2004) and physical exercise (e.g., Armitage, 2005). In organizational research, the theory also has been used to explain environmental, or 'green,' behavior at work (Greaves, Zibarras, \& Stride, 2013; Norton, Parker, Zacher, \& Ashkanasy, 2015), the adoption of new technology (Morris, Venjaesh, \& Ackerman 2005), and organizational change (Jimmieson, Peach, \& White, 2008). Metaanalyses also have provided good support for the theory (e.g., Armitage \& Conner, 2001; Webb \& Sheeran, 2006). 
Integrating political skill and the theory of planned behavior. Considering the above, we integrate Ajzen's (1991) Theory of Planned Behavior and Social/Political Influence Theory (Ferris et al., 2007; Munyon et al., 2015) to propose that efficacy beliefs link political skill and performance, such that political skill leads individuals to feel more confident in their ability to engage effectively in political campaigning. We further suggest that intentions help explain the link between political skill, efficacy, and performance, in that by allowing individuals to accurately diagnose situations, discern motives, and utilize networks to recognize opportunities, political skill should facilitate the formation of behavioral intentions that more realistically match the power and resources required to attain them, thus increasing the likelihood of successful performance.

First, we propose that political skill will be positively related to campaign efficacy. According to social/political influence theory, individuals make intrapsychic appraisals of their personal resources, including self-efficacy, which refers to individuals' beliefs in their ability "to organize and execute courses of action required to produce given attainments" (Bandura,1997, p. 3) through mobilizing "the motivation, cognitive resources, and course of action needed to meet given situational demands" (Wood \& Bandura, 1989, p. 408).

Political skill imbues individuals with a greater sense of control over their environment (i.e., efficacy), because they can more accurately discern the motives and needs of political opponents, leverage relationships to establish coalitions, and control their self- presentation (Ferris et al., 2007; Ferris et al., 2012; Munyon et al., 2015). Individuals who judge themselves to be more capable in the political arena (i.e., that have higher political skill) are, therefore, more likely to approach campaigning with a greater sense of confidence and selfefficacy. Existing research lends empirical support to this assumption, as a recent metaanalysis (i.e., Munyon et al., 2015) found that self-efficacy beliefs mediated the relationship between political skill and performance.

However, research examining political skill and efficacy thus far has focused on generalized self-efficacy (e.g., Jawahar, Meurs, Ferris, \& Hochwarter, 2008; Munyon et al., 2015), a broad evaluative trait that reflects an individual's ability to perform and cope successfully with an extensive range of situations (Chen, Gully, \& Eden, 2001). Along with self-esteem, emotional stability, and locus of control, generalized self-efficacy has been identified as one of the traits making up the higher-order construct of core self-evaluation (CSE: Judge, Locke, Durham, \& Kluger, 1998), which refers to the fundamental and relatively stable self-based appraisals people make of their own self-worth, competence, and capabilities (Chang, Ferris, Johnson, Rosen, \& Tan, 2012). 
Instead, our focus in the present study is on the narrower domain-specific self-efficacy, which concerns individuals' evaluation of their ability to perform in a specific area, such as leadership (Hannah, Avolio, Luthans, \& Harms, 2008). Domain-specific selfefficacy is more malleable (Bandura, 1997; Gist \& Mitchell, 1992), and responsive to experience, training, and development (Day \& Sin, 2011; Lester, Hannah, Harms, Vogelgesang, \& Avolio, 2011; van Knippenberg, van Knippenberg, De Cremer, \& Hogg, 2004). Domain-specific self-efficacy develops gradually through repeated experience (Bandura, 1986), as individuals monitor their performance and base subsequent efficacy judgments on their perceived ability to master tasks or strategies (Bandura, 1991; Mathieu, Martineau \& Tannenbaum, 1993).

The comparative malleability of domain-specific self-efficacy also explains why it has been used both as a predictor of training success (e.g., Stevens \& Gist, 1997), and as an outcome of training effectiveness (Kraiger, Ford, \& Salas, 1993; Lester et al. 2011; Mensmann et al., 2018). Thus, we propose that domain-specific self-efficacy is more pertinent to an investigation like ours, with a restricted performance variable (i.e., electoral success), because it is based on individuals' appraisal of how their political skill will operate in a specific context (i.e., campaigning for election).

Further rationale for focusing on self-efficacy in this context can be found in the political science construct political efficacy, which refers to "the feeling that political and social change is possible and that the individual citizen can play a part in bringing about this change" (Campbell, Gurin, \& Miller, 1954, p. 187). Research differentiates between external political efficacy (i.e., individuals' beliefs in the responsiveness of political officials, governmental authorities, and institutions to citizen demands: Balch, 1974; Condon \& Holleque, 2013; Craig, Nieme, \& Silver, 1990) and internal political efficacy (i.e., individuals' beliefs in their competence to understand and to participate in the political process), with Bandura's concept of self-efficacy linked explicitly with internal political efficacy (Madsen, 1987).

Extensive political science research has shown that individuals with high internal political efficacy are more likely to engage in efforts to influence the political system through membership in political groups, election campaigning, contacting elected officials, and voting in elections (Abramson \& Aldrich, 1982; Cohen, Vigoda, \& Samorly, 2001; Finkel, 1985; Morell, 2005; Rudolph, Gangle, \& Stevens, 2000; Vecchione \& Caprara, 2009). To our knowledge, however, this substantive body of research has focused primarily on the political efficacy of citizens and voters, with little attention paid to the efficacy of political actors (i.e., 
individuals campaigning for, or holding, political office). For the purposes of the present study, we conceptualize individuals' beliefs about their confidence to organize and execute campaign-related activities aimed at winning votes and achieving electoral success, as a form of domain-specific self-efficacy (i.e., 'campaign efficacy').

Hypothesis 1: Political skill is positively related to campaign efficacy.

Second, we argue that domain-specific campaign efficacy contributes to personal intentions that individual political candidates set for themselves during an election campaign. Although Ajzen (2002) refers to 'perceived behavioral control' in the Theory of Planned Behavior, conceptual similarities exist between this social cognitive construct and selfefficacy, one of the fundamental processes involved in self-regulation. In a comparison of perceived behavioral control and self-efficacy, Rodgers, Conner, and Murray (2008) found self-efficacy to be the stronger predictor of health-related intentions and behavior.

Following the Theory of Planned Behavior, we propose that intentions, which indicate "how hard people are willing to try and how much effort they are planning to exert in order to perform the behavior" (Ajzen, 1991, p. 181), are a likely outgrowth of those with higher political skill and efficacy. That is, politically skilled individuals are better able to approach campaigning with a greater sense of confidence in their ability to undertake an effective campaign, and with more accurate evaluations of the environment. Also, these individuals are more likely to identify opportunities to perform well, leading them to develop stronger intentions to personally engage in campaign activities such as fundraising, recruiting activists, and devoting more time to the overall campaign.

Hypothesis 2: Campaign efficacy is positively related to intentions.

Hypothesis 3: Political skill demonstrates an indirect relationship with intentions via campaign efficacy.

Subsequently, we propose that intentions bridge the relationship between political skill, efficacy, and performance. That is, we expect these stronger intentions regarding personal campaign activity to positively impact performance, as theory and research on behavioral intention models have both argued and shown support for the notion that intentions are powerful predictors of performance (Ajzen, 1991; Webb \& Sheeran, 2006; Westaby, 2005). Further, we expect that political skill will be related to performance (i.e., electoral success in our context) through intentions, in addition to efficacy. Thus, we hypothesize that:

Hypothesis 4: Intentions are positively related to electoral performance. 
Hypothesis 5: Political skill demonstrates an indirect relationship with electoral performance via campaign efficacy and intentions.

\section{Method}

\section{Political Context of the Study}

To test our hypotheses, we measure self-rated political skill, campaign efficacy, and intentions among British political candidates at the start of their campaign to be elected as an MP. Our participants are commensurable; each parliamentary candidate in our sample had equal opportunity to engage in efforts to influence voters. Furthermore, because our sample is from a single political party - the Liberal Democrats, and we were able to control for the percentage of vote in the previous general election, it was possible to examine the candidates' individual impact on votes beyond party allegiance. Thus, our hypotheses can be tested in an environment where it is possible to identify the impact of each political candidate's political skill, efficacy, and personal campaign intentions (Farber, 1952; Highhouse \& Gillespie, 2009).

\section{Participants}

The British Parliament is comprised of 650 MPs, each of whom represents a constituency (or 'seat') in England, Scotland, Northern Ireland, or Wales. Like the U.S., there are two main political parties (right of center and left of center). In 2010 these held $92.3 \%$ of seats with the remaining $7.7 \%$ (i.e., 87) held by smaller political parties. All participants in this study were parliamentary candidates campaigning for the same political party - the Liberal Democrat Party, which meant that we could control for national swing. As the third largest political party, the Liberal Democrats usually field candidates in nearly all constituencies $^{3}$, but return fewer MPs to Parliament. In our sample, just $8 \%$ of candidates were thought to have a realistic chance of winning the seat ${ }^{4}$. Therefore, although winning is an overall goal in political elections, the primary function of most candidates in our sample was to lead a political campaign that would raise their Party's profile, increase the Party's share of votes in their constituency and, where possible, gain sufficient votes to win the seat. The Liberal Democrat Party went on to win 57 seats in the 2010 general election and, as no party won an overall majority, agreed to form a coalition government with the Conservative Party; the first coalition government in Britain in over fifty years.

\footnotetext{
${ }^{3}$ Political parties do not traditionally contest the Speaker's seat, and Northern Ireland has a different party structure, thus the Party contested 631 seats in total.

${ }^{4}$ Information provided by the Party's Campaign Department.
}

This article is protected by copyright. All rights reserved 
A total of 225 parliamentary candidates (i.e., a 38.1\% response rate) provided selfratings pre-election. We consider this a good response rate because political candidates are a difficult population to access for research (Simonton, 1998), particularly just before they begin campaigning.

\section{Procedure}

Data from candidates were captured using an online questionnaire. Approximately three months ${ }^{5}$ before polling day for the 2010 General Election, and two months before the official start of the campaign, all Liberal Democrat parliamentary candidates in England, Wales, and Scotland $(n=631)$ were contacted by the Party's Candidates Office, and asked to take part in a study aimed at understanding how pre-election support for candidates might be improved. Candidates were provided with a link to the questionnaire, and they were asked for permission to use anonymized data as part of a university research study investigating factors that influence political candidate success.

\section{Measures}

Political skill was assessed using the 18-item Political Skill Inventory (PSI: Ferris et al. 2005). The PSI has sub-scales for each of the four dimensions (i.e., social astuteness, interpersonal influence, networking ability, and apparent sincerity), but most studies report a composite score for political skill based on the average response to all 18 items. Items are rated using a five-point scale $(1=$ strongly disagree and $5=$ strongly agree $)$, and examples include: "I am good at using my connections and network to make things happen," "I pay close attention to people's facial expressions," and "I understand people very well." Research has shown the PSI to have good internal reliability, which also was the case in the present investigation $(\alpha=.91)$.

Campaign efficacy was measured using three items that assessed candidates' domain-specific confidence in relation to increasing their share of the vote, achieving their campaign targets, and winning the seat (Bandura, 2006). Following Rodgers et al. (2008) and Stevens and Gist (1997), the items (e.g., 'how confident are you that you will significantly increase your share of the vote in this constituency?') were rated on a ten-point scale, where $1=$ not confident at all and $10=$ totally confident $(\alpha=.67)$.

Intentions was assessed using five items, each of which related to a candidate's personal intention to engage in a different campaign-related activity. These are activities that

\footnotetext{
${ }^{5}$ Although, by convention, the Prime Minister gives one month notice of a general election, the date of the 2010 general election had been widely anticipated as the $6^{\text {th }}$ of May. Consequently, political parties had already selected virtually all parliamentary candidates.
}

This article is protected by copyright. All rights reserved 
are routinely monitored by political parties and used by political scientists to investigate campaign behavior (i.e., contacting voters; public speaking events; activist recruitment; time devoted to campaign, and fundraising: Barber, Canes-Wrone, \& Thrower, 2017). Although our intentions measure might appear similar to 'campaign intensity' scales used in political science (c.f. Fieldhouse, Fisher, \& Cutts, 2019), these scales typically rely on information that candidates and political parties are required to publish after the election (e.g., candidate spending: Fisher, Johnston, Cutts, Pattie, \& Fieldhouse, 2014), and post-election surveys of campaign activities within constituencies, usually completed voluntarily by political parties and campaign agents (c.f. Fisher \& Denver, 2008, 2009).

In this study, our primary focus was different in that we asked individual candidates to self-report their personal intention to engage in campaign activities prior to the start of their campaign. The specific wording of each item (provided below) was discussed with, and approved by, members of the Campaign Office. This was done to ensure that each item was relevant to the party and reflected a distinct campaign activity expected of all party candidates; that each scale accurately reflected the full range of activity anticipated of candidates campaigning in different seats (e.g., safe, marginal), and to agree on a format that would be relatively easy to complete by likely busy candidates preparing for the general election.

Consequently, all five items were assessed using a four-point scale and measured: (1) intended voter contact - 'on average how many voter contacts are you personally planning to make per week between now and the general election' (where $1=25$ or less voters, $2=26$ to 50 voters, $3=51$ to 100 voters, 4 = more than 100 voters); (2) intended communication 'how many public speaking engagements are you planning to make per week between now and the general election' (where $1=5$ or less engagements, $2=6$ to 10 engagements, $3=11$ to 15 engagements, and 4 = more than 15 engagements); (3) intended activist recruitment 'how many new activists are you planning to recruit between now and the general election?' (where $1=1$ to 10 activists, $2=11$ to 25 activists, $3=26$ to 50 activists, and $4=$ more than 50 activists); (4) intended campaign time - 'on average, how many hours per week are you planning to spend on your campaign between now and the general election' (where $1=5$ hours or less, $2=6$ to 10 hours, $3=11$ to 20 hours, and $4=$ more than 20 hours); and (5) intended fundraising - 'how much money are you personally planning to raise?' also using a four-point scale, where each scale point corresponded to a range of values, measured in U.K. pounds. Specific fundraising targets are withheld due to a confidentiality agreement with the Party that aided in data collection. Internal consistency reliability for this scale was $\alpha=.73$.

This article is protected by copyright. All rights reserved 
Electoral performance. Because candidates were attempting to influence constituents to vote for them, we assessed performance using results from the 2010 British general election. Specifically, we operationalized performance as the percentage of votes secured by candidates in their constituency during the 2010 general election.

Control variables. Because elections are likely to be influenced by a number of candidate and contextual factors (Stevens et al., 2019), we included additional control variables in efforts to both isolate the effects of our focal variables and reduce concerns regarding endogeneity.

Gender was included as a control because it has been suggested that women may find it difficult to access development opportunities for political skill (Perrewé \& Nelson, 2004), and also experience bias from voters (Bock, Byrd-Craven, \& Burkley, 2017).

Age was included as a control because research has shown that older individuals may be more politically skilled (Oerder, Blickle, \& Summers, 2014), and may be perceived as more competent by voters (Olivola \& Todorov, 2010).

Prior campaign experience can be considered a relevant developmental experience that affects candidates' political skill (Ferris et al., 2007; Krebs, 2001). It also provides candidates with exposure to campaign activities that may provide them with greater confidence in their influence strategies and intentions. Our sample included 96 first-time candidates, and 105 who had stood for election at least once. Prior campaign experience was measured by asking respondents to indicate in how many of the six general elections between 1983 and 2005 they had stood as a parliamentary candidate.

Incumbency is an important consideration for candidates' decision to stand for election, and it could affect their skill and campaign efficacy (Dawes \& Bacot, 1998; Maisel $\&$ Stone, 1997). Therefore, we included a "yes/no" measure of whether the candidates stood in the previous (i.e., 2005) general election in the same constituency as for their 2010 campaign.

Facial appearance of politicians was included as a control variable because research has suggested traits often are inferred from political leaders' facial appearance, and that these inferred traits can influence voters' decisions during elections (Campbell \& Cowley, 2014; Olivola \& Todorov, 2010; Wyatt \& Silvester, 2018). To assess the impact of facial appearance in our sample of politicians, we recruited 461 participants (268 were men, average age was 27.15), via Prolific Academic, a British crowdsourcing research platform. To avoid politicians being recognized, we recruited a non-British sample, which comprised 352 
participants from mainland Europe, 88 from North America, and the remaining participants from Africa (4), South America (8) and Australasia (9).

We were able to obtain headshots for 190 of the politicians in our sample, which we standardized in size and converted to greyscale, following procedures in Todorov, Mandisodza, Goren, and Hall (2005). The 461 participants were randomly assigned to one of six conditions: attractiveness $(n=75)$, competence $(n=79)$, intelligence $(n=76)$, likeability ( $n=77)$, trustworthiness $(n=78)$, and whether they would vote for the individual in a political election ( $n=76$ ). Following Dietl, Rule, and Blickle (2018), we conducted a principal components analysis with varimax rotation on the average ratings for each trait, which yielded a single factor, accounting for $72.02 \%$ of the variance with all factor loadings above .70. We therefore combined the six trait inferences into a single 'facial appearance' measure $(\alpha=.92)$.

Seat 'winnability' was assessed by members of the Party's Campaign Office, who are responsible both for oversight of the party's central campaign strategy and estimating the likelihood that a seat can be won ${ }^{6}$. This was assessed using a four-point scale ranging from 1 $=$ most winnable to $4=$ least winnable. As a smaller political party, relatively few seats (i.e., approximately $8 \%$ ) were considered safe or marginal.

Economic context is an important consideration for any model predicting electoral outcomes (Fair, 2009). For example, perceptions of economic insecurity are likely to encourage voters to support incumbent governments (Helgason \& Merola, 2017). Therefore, we included the employment rate, which is the percentage of people in work for each constituency, as a control variable. These figures were sourced from the U.K. Annual Population Survey for 2010 (Office for National Statistics, 2010).

Prior electoral performance was also controlled for because candidates' confidence and intention to engage in campaigning might be based in part on their belief about how well their political party is regarded by their constituents. For example, in seats where the party has been more successful in previous elections, candidates might be more motivated to engage in campaign activities. Importantly, because all candidates were from the same political party, it was possible to control for national swing, or change in voter support, in electoral performance. Likewise, controlling for prior success in each seat also allowed us to

\footnotetext{
${ }^{6}$ Winnability refers broadly to whether a seat is considered 'safe' (i.e. held with a strong lead on other parties), 'marginal' (i.e. either held with a small margin, or where the party has a reasonable chance of gaining control), 'moving forward' or 'development' (i.e. lower and least likelihood of the party winning control). It depends on multiple factors including how the party has performed in the seat in previous elections, how the party is performing nationally, and recent change in economic or political circumstance.
}

This article is protected by copyright. All rights reserved 
control for the popularity of the political party. Prior electoral performance was measured using the percentage of votes received by the Party in each seat in the 2005 general election.

\section{Data Analyses and Results}

We compared the demographics of our sample $(N=225)$ to all 631 candidates who stood for election from the same party using data from the British General Election Constituency Results (Norris, 2010) and the Parliamentary Candidates project (Lamprinakou, 2015). Our sample was broadly representative: $72.4 \%$ were male $(n=163)$, compared to $75.12 \%$ in the wider party $\left(\chi^{2}(1)=.86, p>.05\right)$, and although our sample comprised more non-white individuals than the wider party $\left(16.44 \%\right.$ and $6.51 \%$ respectively: $\chi^{2}(1)=34.57, p$ $<.05)$, the majority of our sample $(83.6 \%)$ described themselves as 'white British,' which was in line with $93.49 \%$ in the wider party.

Participants also reported falling within the same average age group $(M=44.80)$ of the wider party (40-59). A review of the data provided by respondents revealed that 24 respondents omitted the majority of items (i.e., over 60\%) for scales of the focal study constructs. As a result, these cases were deemed to be missing not at random (Newman, 2009), and were excluded from our data analysis. Table 1 shows means, standard deviations, and correlations for all study variables. Candidates in winnable seats were more likely to be men, although women candidates reported higher political skill and campaign efficacy, were rated more attractive, and received more votes in their constituencies.

\section{Insert Table 1 about here}

The hypotheses were tested using the structural equation modelling (SEM) command in STATA 15, which allowed us to combine the latent variables political skill, campaign efficacy, and intentions, and observed control and outcome (electoral performance) variables in the same model, and enabled analysis of the full sample $(N=201)$ using the maximum likelihood with missing values (MLMV) estimator. Because the Political Skill Inventory consists of 18 items, we were concerned about the number of parameters required to estimate our overall model using SEM, given our final sample size. Using all individual items as latent variable indicators, as opposed to parcels, "makes it less likely that the model will fit well even if it closely matches the process being studied" (Williams \& O’Boyle, 2008, p. 236). Thus, a latent variable was created for political skill with parcels as indicators using the 
domain representation approach (Williams \& O’Boyle, 2008), such that each parcel consisted of items representing all four political skill dimensions.

For multidimensional constructs to be examined at the composite construct level, Williams and O'Boyle (2008) argued that the domain representation approach was more appropriate than one in which a separate parcel was created for each individual dimension (i.e., the internal consistency approach, as prior research has shown that internally consistent parcels are associated with unstable parameter estimates; Little et al., 2002; Williams \& O'Boyle, 2008). Thus, because only three survey items exist for the apparent sincerity dimension, three parcels were created for political skill so that apparent sincerity would be represented in each parcel. After that, we followed the accepted practice of placing the items in each parcel in order. That is, the first social astuteness item went to the first parcel, the second social astuteness item to the second parcel, continuing until all items have been assigned.

Before assessing the structural model, we conducted confirmatory factor analyses (CFA) to assess whether our measures of political skill, campaign efficacy, and intentions measured distinct concepts. To indicate a good model fit, we considered chi-squared $\left(\chi^{2}\right)$, RMSEA values below .06, CFI and TLI values above .95, and to identify the best model in model comparisons we looked for the lowest values for Akaike's information criterion (AIC) and Bayesian information criterion (BIC: Hu \& Bentler, 1999). When treated as three separate factors, the CFA demonstrated good fit $\left(\chi^{2}(41)=45.89, p=.28, \mathrm{CFI} / \mathrm{TLI}=.99 / .99\right.$, RMSEA =.02). As shown in Table 2 , this model demonstrated a significantly better fit, with the lowest AIC (4956.73) and BIC (5075.66) values than a series of two-factor models, where political skill, campaign efficacy, and intentions were analyzed in various combinations to form two factors, as well as when all items were loaded onto the same factor. Because the three-factor model provided a significantly better fit, we were confident that our measures captured distinct constructs.

Insert Table 2 about here

Because political skill, campaign efficacy, and intentions were measured using the same self-report survey, there is a risk of common method variance (CMV) bias. Thus, we tested the possibility of CMV using the marker technique outlined by Williams, Hartman, and Cavazotte (2010). This technique uses items theoretically unrelated to the substantive 
variables as a marker variable. In our survey, we collected data for several additional variables of interest to the political party, measured on a 1 (strongly disagree) to 5 (strongly agree) Likert scale. Therefore, we used three of these items concerned with political values (e.g., "My actions always reflect my values"), a construct that is not related theoretically to political skill, campaign efficacy, or intentions, in order to construct our latent marker variable.

The Williams et al. (2010) procedure specifies the analyses of five nested CFA models to examine the influence of CMV. Model 1 allows variables to correlate and be estimated freely. Model 2 forces correlations between the marker variable and all other variables to zero, and it fixes the marker variables' parameters to values acquired from Model 1. Model 3 adds factor loadings between the marker variable and other variables, but it constrains them to be equal. Model 4 then allows these added loadings to be freely estimated. Finally, Model 5 is identical to Model 4, but the correlations between variables are constrained to their values from Model 2. We found that our Model 5 did not fit the data better than Model $4\left(\Delta X^{2}=1.61, d f=3, p>.05\right)$, which provides evidence that the relationships in the model are not significantly biased by method variance.

For our hypothesis tests, we specified a structural model using political skill, campaign efficacy, and intentions as sequential latent variables, with indicators as outlined above, to predict electoral performance in the 2010 general election (an observed variable). Additionally, we included observed variables for the following controls: gender, age, facial appearance, prior campaign experience, incumbency, seat, economic context, and prior electoral performance (i.e. percentage of votes in the 2005 general election). The three parcels for political skill loaded well onto the latent variable, ranging between .89 and .93. The three indicators for campaign efficacy loaded significantly onto the latent factor between .48 and .76. The five indicators of the latent factor intentions loaded significantly between .37 and .74 .

Our model demonstrated a reasonably good fit for the data $\left(\chi^{2}(116)=194.77, p<.01\right.$, $\mathrm{CFI} / \mathrm{TLI}=.94 / .92 ; \mathrm{RMSEA}=.06, \mathrm{AIC}=11629.93, \mathrm{BIC}=12006.51)$. Figure 1 shows the standardized coefficients for our structural model, including control variables. As hypothesized, political skill was positively and significantly related to campaign efficacy $(.41, p<.01)$, which was positively and significantly related to intentions $(.61, p<.01)$, which was positively and significantly related to electoral performance in the 2010 election $(.20, p<.01)$. Thus, the results supported all hypothesized structural relationships. 
Insert Figure 1 about here

Indirect effects were calculated using a sandwich estimator (Huber, 1967; White, 1982) to provide estimates based on robust standard errors (Antonakis, Bendahan, Jacquart, \& Lalive, 2010) . As reported in Table 3, the indirect relationship between political skill and intentions via campaign efficacy was significant $(.25, p<.01)$, as well as the indirect relationship between political skill and electoral performance, via campaign efficacy and intentions $(.05, p<.01)$, and the indirect relationship between campaign efficacy and electoral performance $(.12, p<.01)$. Because we did not hypothesize direct effects, these were not included in the model for parsimony (Aguinis, Edwards \& Bradley, 2017).

However, preliminary analysis of total and direct effects between political skill and intentions $(.20, p<.01$ and $-.08, p>.05$, respectively), and between political skill and electoral performance $(-.05, p>.05$ and $-.15, p<.01$, respectively), suggests that the positive effect of political skill on electoral outcomes occurs indirectly via campaign efficacy and intentions. Examining the unstandardized coefficients shows that an increase of one scale point on the Political Skill Inventory is associated with a $.78 \%$ increase in percentage of the vote (SE = .23). Likewise, an increase of one scale point on the campaign efficacy scale is associated with an increase of $.55 \%$ in percentage of the vote $(S E=.16)$. These results provided support for Hypotheses 3 and 5, respectively.

Insert Table 3 about here

Because political skill, campaign efficacy, and intentions all were measured at the same time, we lacked the temporal separation required to empirically examine the causal nature of our model. Therefore, to increase confidence that our results are reflective of our theory, we ran several alternative models. First, we ran a model in which we reversed the positions of political skill and campaign efficacy variables. The model was a worse fit than our hypothesized model $\left(\chi^{2}(116)=241.40, p<.01 ; \mathrm{CFI} / \mathrm{TLI}=.91 / .87, \mathrm{RMSEA}=.07\right)$, with increased AIC (11676.56) and BIC (12053.14) values. Second, we ran a model where political skill and campaign efficacy were treated as joint predictors of electoral performance via intentions, which was also a worse fit than our hypothesized model $\left(\chi^{2}(116)=220.42, p\right.$ $<.01 ; \mathrm{CFI} / \mathrm{TLI}=.92 / .89, \mathrm{RMSEA}=.07, \mathrm{AIC}=11655.58, \mathrm{BIC}=12032.16)$, and while 
campaign efficacy was a significant predictor of intentions $(.64, p<.01)$, and intentions predicted electoral performance $(.21, p<.01)$, the relationship between political skill and intentions was non-significant $(-.02, p>.05)$, as was the indirect relationship between political skill and electoral performance via intentions (-.00, $p>.05$ : see Table 3$)$. The results from these alternative models suggest that political skill is better placed as a distal predictor, with campaign efficacy and intentions as the explanatory mechanisms between political skill and electoral performance ${ }^{7}$.

Finally, in order to examine whether being an experienced candidate $(N=96)$ was more advantageous than being a first-time candidate $(N=105)$, we compared our hypothesized model across these two groups, removing the controls concerning prior campaign experience, incumbency, and seat as these are closely related to candidates' experience. The model showed a better fit for candidates who were standing for election for the first time $\left(\chi^{2}(100)=125.86, p>.05\right)$ as opposed to experienced candidates $\left(\chi^{2}(100)=\right.$ $175.89, p<.01$ ), although Wald tests showed no significant differences between the groups on any of the models' parameters.

\section{Discussion}

\section{Contributions to Theory and Research}

Despite longstanding academic and public interest in psychological characteristics that contribute to political success, very few studies have investigated candidates' selfreported characteristics and their relevance for campaign activity and electoral performance (Stevens et al., 2019). The present study addresses this lacuna by examining the personal resources (i.e., political skill and campaign efficacy) that political candidates draw on to help form their personal intentions to campaign and secure votes during a national election. In doing so, it also attends to claims that, despite much evidence substantiating links between political skill and individual performance, research investigating the mechanisms that underpin this link have lagged behind (cf. Ewen et al., 2013; Ferris et al., 2012).

By integrating Social/Political Influence Theory (Ferris et al., 2007; Munyon et al., 2015) and the Theory of Planned Behavior (Ajzen, 1991), our study investigated whether actors' intentions constitute an important explanatory mechanism, bridging the gap between intrapsychic processes. We proposed that political skill is associated with individuals (i.e., candidates) feeling more confident (i.e., higher levels of campaign efficacy), and with setting

\footnotetext{
${ }^{7}$ We also examined a three-way interaction between political skill, campaign efficacy, and intentions on electoral performance but found that neither the two-way nor three-way interactions were significant.
}

This article is protected by copyright. All rights reserved 
more ambitious intentions, that in turn result in heightened performance (i.e., increased percentage of the vote).

Testing these predictions with a novel sample of parliamentary candidates campaigning in a British general election, we found statistically significant positive relationships between political skill and campaign efficacy, between campaign efficacy and intentions, and between intentions and electoral performance. We also found significant indirect effects of political skill on performance through intentions, and between political skill and intentions through campaign efficacy, providing support for all study hypotheses.

Our results are notable in that they derive from an objective measure of performance (i.e., percentage of the vote achieved by a candidate in an election), while controlling for personal characteristics, such as candidates' age, gender, facial appearance, campaign experience, as well as the wider economic context, type of seat, and prior electoral performance in that constituency. In political elections, voters typically choose to vote along party lines (Denver, Carman, \& Johns, 2012), but our results support claims that candidate characteristics also can play a role in electoral performance (Winter, 1987). We found that a one-unit increase in candidate political skill was associated with a .78\% increase in percentage of the vote. Although not large, this is a case where small effects have the potential to "tell a big story" (Cortina \& Landis, 2009), particularly given that in Britain, only a .10\% change in vote share is necessary to swing some marginal seats to an alternative party (Dempsey, 2017).

Our findings contribute to the literature in two ways. First, integrating theories of political influence and planned behavior, we introduce domain-specific self-efficacy and intentions as constructs that elucidate the relationship between political skill and objective performance outcomes. Secondly, in capturing self-report measures of political skill, efficacy, and intentions from political candidates ahead of a national election, we demonstrate the relevance of psychological factors in campaigns for attaining non-traditional leadership roles like legislator, for performance in political work settings like governmental politics, and for traditional leadership roles attained via elections and tournaments.

The unique nature of our sample and parliamentary setting (i.e., where hundreds of political candidates contest seats over the same fixed period with relatively little support from their political party) enabled us to show the potential value of political skill and campaign efficacy in political elections. Therefore, our findings add to previous research that found a positive relationship between the self-rated political skill of politicians in office and performance ratings received from colleagues (Silvester et al., 2014), and provide further 
evidence that political skill's effectiveness likely extends beyond employees and traditional work environments.

\section{Limitations and Future Research Directions}

Our sample represents a strength of the current research, because all political candidates had a common goal (i.e., to win votes), and were working within the same time period under similar conditions to achieve an objective measure of performance (i.e., percentage of votes). However, candidate effects can be particularly hard to discern in Westminster-type parliamentary systems, where national and partisan factors can exert a powerful sway on voter choices (Gaines, 1998). Moreover, despite strong ecological validity in field studies (Sieweke \& Santoni, 2020), our research context (i.e., candidates campaigning in a national election) placed constraints on what information could be collected and when.

Our research design was determined in part by the access we were granted by the political party, and a need to address their interests. This meant that we were limited in what constructs we could assess, and that we were unable to survey candidates more than once due to concerns about over-burdening them during the campaign. Despite making design accommodations to this end, the potential perceived time burden likely impacted our response rate. Thus, the size of the sample used to test the model was relatively small, and this combined with the number of parameters likely impacted the model fit, which while reasonable, could be improved with a larger sample (Sharma, Mukherjee, Kumar, \& Dillon, 2005; Schermelleh-Engel, Moosbrugger, \& Müller, 2003).

Our sample of political candidates in a national election also meant we had to use non-British ratings of facial appearance to ensure candidates' identity was not known to raters. Although using naïve participants is recommended when gathering inferences based on facial appearance (Todorov et al., 2005), and there is some evidence that evaluations of faces generalizes across cultures (Walker, Jiangm Vetter \& Sczesny, 2011), future research should consider the impact of cross-cultural differences in such trait ascriptions for political candidates.

We were also were limited in what constructs we could assess. For example, our efficacy measure had to be succinct and relevant to the overall party aims, resulting in a lower reliability ( $\alpha=.67$ ). This suggests that future research should aim to develop a measure of campaign efficacy with greater reliability in samples where campaign targets may be heterogenous. 
Difficulty accessing political candidates also meant our measures of political skill, campaign efficacy, and intentions were collected from the same source at the same time, limiting our ability to claim that the relationships between these variables were causal, and generating potential concerns regarding common method variance (CMV). In efforts to address these, we employed traditional methods of minimizing bias, such as different response scales used across the constructs in our model (Podsakoff, Mackenzie, \& Podsakoff, 2012). We also used the CFA marker variable technique (Richardson, Simmering, \& Sturman, 2009) to assess statistically the degree to which CMV was a concern. Although the CFA marker variable technique has practical value in testing for the presence of CMV, its utility can be limited if marker items are chosen post-hoc. Therefore, future studies should consider collecting self-report data at multiple time points from candidates before, and possibly during, an election campaign.

In our study, we also controlled for the type of seat (i.e., winnability) using the political party's rating of likely electoral success. However, it could be argued that candidates are likely to perform better in more winnable seats because they have more campaign resources, and, potentially, because political parties place stronger candidates in more winnable seats ${ }^{8}$. Taking the first of these, we demonstrate that even controlling for whether a seat is held or a target for the party (i.e., priority seats where a political party might direct more support, such as high profile visits to the constituency from party grandees), the effects of candidate political skill, campaign-efficacy, and intentions are still significant. Moreover, our sample came from a smaller political party, where only a very small proportion of candidates (i.e., approximately 8\%) were considered to have a realistic chance of winning control. Consequently, the availability of central campaign resources was limited, and all candidates were expected to take a lead in building and mobilising their campaign team locally.

Evidence from political science research suggests that candidates' local campaigns can affect their individual electoral fates, regardless of how the national campaign fares (Pattie et al. 2019), and that the effectiveness of local campaigns is influenced by districtlevel conditions such as the local economy (e.g., Fieldhouse et al., 2019; Pattie \& Johnston, 2016), which we controlled for in our study. However, future research might take a more granular approach to exploring further variables like actual candidate spending and campaign activity throughout the campaign period.

\footnotetext{
${ }^{8}$ We thank an anonymous reviewer for their comments here.
} 
To date, very little research has drawn upon organizational psychology work to understand how to help candidates develop the political skill, efficacy, and knowledge required for political work and effective campaigning. Thus, future studies might also take a more detailed look at candidate characteristics and their work to engage and motivate campaign teams within constituencies. Interestingly, although not a primary focus, our study also found that women candidates self-reported higher political skill, campaign efficacy, and electoral performance, but were more likely to be fighting in less winnable seats; this may well indicate a pool of women candidates capable of success in more winnable seats in future elections.

It is also unlikely that our results are due to 'favoured' (or better) candidates being placed by the party in more winnable seats. The possibility that political parties 'parachute favorite sons and daughters' into more winnable seats (Norris, Carty, Erikson, Lovenduski, \& Sims, 1990) has been the focus of considerable debate in political science (e.g., Norris, 2004) and, for many years, a particular source of contention within political parties (e.g., Lovenduski, 2005). In fact, candidate selection practices vary considerably across national and political contexts, and in some national parliamentary contexts, it is acceptable for political parties to place candidates in local constituencies (Koop \& Bittner, 2011).

However, in Britain, most local party associations are, traditionally, fiercely protective of the right to select their own parliamentary candidate (Norris, 2004). Therefore, in order to maintain standards, political parties (i.e., including the Liberal Democrat Party in our study) typically utilise a two-stage process, where all aspiring candidates participate in a formal assessment process, managed by the party's central candidates committee. As part of this process, an individual must demonstrate competence against a series of criteria before being approved as prospective parliamentary candidate and allowed to apply to a local seat. Consequently, local party members retain control over their preferred choice of parliamentary candidate, while the party controls standards (Childs, 2015; Silvester, 2012). Thus, future research might build on our results to consider the impact of personal resources and characteristics on fighting for selection to stand as a party candidate - a process that largely is hidden and regulated by party rules and informal practices (Bjarnegård \& Kenny, 2015).

Finally, as the majority of candidates in our sample would have had little chance of winning in their seat, it is worth questioning how motivated or engaged they actually were in their campaign. Because fighting for seats with little likelihood of winning is a common challenge for smaller political parties, there are several reasons why candidates, and the political party, are motivated to campaign strongly in these seats. First, general elections 
represent an important setting for political parties keen to communicate their vision and values to a national audience: thus making sure that all candidates are fully engaged in campaigning helps to maximise the reach and impact of the party and its campaign message.

Secondly, first-time candidates frequently 'cut their teeth' in a less winnable seat in order to gain experience and demonstrate their potential before applying to a more winnable seat in future elections. We control for candidate experience in our study because this enables candidates to develop relevant knowledge and skill. Much existing research focuses on central or 'party' campaigns, rather than the individual resources candidates need to be effective in their individual campaign. Future research could further investigate the knowledge, skills and competences associated with successful campaigning.

Thirdly, in many constituencies, local government is controlled by a different political party from that of the Member of Parliament. At the time of the 2010 general election, the Liberal Democrat Party had a strong presence in local government, with many local councillors representing local wards. As such, there was a strong incentive for local candidates to campaign hard even in less winnable seats, because the campaign also served to promote the party's work and activity locally.

Our model and findings indicate that the psychological characteristics of individual candidates can contribute to performance outcomes in elections. However, effect sizes are small, and as the data relate to a single political party, there is still a question of how generalizable these findings might be to candidates from different political parties, election contexts, and types of seat. For example, it is possible that in larger political parties, which have greater capacity to target central campaign resources at key marginal seats, candidate characteristics may play a less important role in campaign outcomes compared to less winnable seats ${ }^{9}$. Although we control for type of seat in our study, future research is needed that captures self-report data from candidates campaigning in different types of seats (i.e., marginal and development), and from political parties of different sizes.

Drawing on political science research (e.g., Fieldhouse, Fisher, \& Cutts, 2019; Johnston \& Pattie, 2006), it would be helpful also to capture more detailed information about campaign activity and, specifically, dedicated central party support and intervention, in order to fully determine the relative contribution of candidate effects in different types of seats. Likewise, further insight could be gained by exploring the potential impact of different political systems and types of legislatures. For example, whereas local elections typically lack

\footnotetext{
${ }^{9}$ We thank an anonymous reviewer for this observation.
} 
the popularity and media attention paid to national elections, they could provide a more accessible research context in which to explore these questions and evaluate the contribution of candidate effects to election performance.

Additionally, our results demonstrate the richness of governmental politics, more generally, as a setting for organizational science research. For example, the activists who lobby and campaign for candidates may provide equally fruitful targets for understanding characteristics associated with campaign success (e.g., does the political skill of activists in a campaign team impact on success - and can this be developed?). Since 2010, there has been an exponential increase in the use of social media by political candidates as part of campaign strategies (Conway, Kenski, \& Wang, 2015), which are not subject to the same controls as national media outlets (Electoral Commission, 2019).

Further research might examine candidate characteristics such as campaign efficacy and the amount and persuasiveness of political communication (Ramey et al. 2016). Finally, as theory can be built through horizontal contrasting (Fisher \& Aguinis, 2017), researchers might consider replicating our research in other tournament settings, such as the election of union representatives, local elections, or in business contexts such as the election of partners in professional service firms. Doing so would shed light on the extent to which our findings generalize to other contexts.

\section{Practical Implications}

In the past two decades, both scholars and practitioners have suggested political skill of elected officials as a key characteristic associated with their performance and effectiveness, providing some very interesting thoughts and observations (e.g., Ferris, Perrewé, Ellen, McAllister, \& Treadway, 2020; Greenstein, 2004). Our results suggest several important practical ways to help individuals become more politically mature, and effective at campaigning in political and traditional contexts. In governmental work, due to lack of resources, a desire to appear neutral, or possibly lack of political will, there is often little in the way of developmental support offered to political candidates (Silvester \& Wyatt, 2018). Yet, our findings suggest that individuals and groups (e.g., trainers and political campaign teams) might do well to focus on enhancing political skill and feelings of efficacy in political candidates, to motivate and enable them to set appropriate and sufficiently challenging personal campaign intentions. This is particularly relevant for improving the success of women and minority candidates, who traditionally have lacked opportunity to gain political knowledge compared with more privileged peers (Murray, 2014). 
Our findings also may be relevant to roles in traditional work contexts that require campaigning and building support from others to succeed. For example, there are similarities between politicians, lawyers, and sales people in their need to develop sophisticated influence tactics (Stern \& Westphal, 2010). Also, CEOs have been likened to political candidates in their need to develop campaign strategies to secure support from allies, and persuade or deflect others who wish to block or subvert decisions (Canella \& Shen, 2001; DeVries, 1988).

Additionally, entrepreneurs seeking financial support from venture capitalists must persuade stakeholders for support via campaign work comparable to that of political candidates (Tocher, Oswald, Shook, \& Adams, 2012). Likewise, change agents campaign to promote knowledge, propagate innovation, and sell ideas to influential others as part of successful internal corporate venturing (Bakker, Boersma, \& Oreel, 2006). Thus, although the specifics of these traditional work settings might differ from that of our political sample, there are related aspects of the mechanisms in play that can offer more general insight.

Therefore, future research could confirm and extend our findings by: collecting data on political skill, campaign efficacy, and intentions, at three separate time points, to more accurately assess causal relationships; exploring the variables set out in our model, and additional variables to explore mediating relationships, and; investigating the relationship between political skill, campaign efficacy, intentions, and electoral performance in different types of political parties and political systems. Additionally, future studies might benefit from incorporating additional control measures, such as candidate campaign expenditure reported post-election, or performance ratings provided by campaign agents for individual candidates, to further tease out the contribution of different psychological characteristics.

\section{Conclusion}

The present research sheds light on the personal resources (i.e., political skill and campaign efficacy) and strategies (i.e., intentions) that may be important for success during political and traditional work. Our research is unusual in focusing on political candidates and campaign work, but some of the most important and challenging questions lie at the intersection of traditionally siloed academic domains. Perhaps the most exciting opportunity for future research is therefore the possibility of applied psychologists working with political scientists to investigate and address one of the most important challenges of our age, namely, - how do we get the politicians who will enable and achieve strong democratic government? 


\section{References}

Abramson, P.R., \& Aldrich, J.H., (1982). The decline of electoral participation in America. American Political Science Review, 76(3), 502-521. doi: $10.1017 / \mathrm{S} 0003055400188379$

Aguinis, H., Edwards, J. R., \& Bradley, K. J. (2017). Improving our understanding of moderation and mediation in strategic management research. Organizational Research Methods, 20(4), 665-685.

Ajzen, I. (2002). Perceived behavioral control, self- efficacy, locus of control, and the theory of planned behavior. Journal of Applied Social Psychology, 32(4), 665- 683. 10.1111/j.1559-1816.2002.tb00236.x

Ajzen, I. (1991). The theory of planned behavior. Organizational Behavior and Human Decision Processes, 50(2), 179-211. doi: 10.1016/0749-5978(91)90020-T

Ajzen, I. (1987). Attitudes, traits, and actions: Dispositional prediction of behavior in personality and social psychology. Advances in Experimental Social Psychology, 20, 1-63. doi: 10.1016/S0065-2601(08)60411-6

Antonakis, J., Bendahan, S., Jacquart, P., \& Lalive, R. (2010). On making causal claims: A review and recommendations. The Leadership Quarterly, 21(6), 1086-1120. doi: 10.1016/j.leaqua.2010.10.010

Antonakis, J., \& Eubanks, D.L. (2017). Looking leadership in the face. Current Directions in Psychological Science, 26(3), 270-275.

Armitage, C.J. (2005). Can the theory of planned behavior predict the maintenance of physical activity? Health Psychology, 24(3), 235-245

Armitage, C.J., \& Conner, M., (2001). Efficacy of the theory of planned behaviour: A metaanalytic review. British Journal of Social Psychology, 40(4), 471-499.

Bakker, H., Boersma, K., \& Oreel, S., (2006). Creativity (Ideas) management in industrial R\&D organizations: A crea- political process model and an empirical illustration of corus RD\&T. Creativity and Innovation Management, 15(3), 296- 309. doi: 10.1111/j.1467-8691.2006.00397.x

Bandura, A. (2006). Guide for conducting self-efficacy scales. In T. Urdan \& F. Pajares (Eds.), Self-efficacy beliefs of adolescents (pp. 307-337). Oxford: Information Age.

Bandura, A., (1997). Self-efficacy: The exercise of control. London: Macmillan.

Bandura, A., (1991). Social cognitive theory of self-regulation. Organizational Behavior and Human Decision Processes, 50, 248-287. 
Bandura, A., (1986). Social foundations of thought and action. Englewood Cliffs, NJ: Prentice-Hall.

Balch, G. (1974). Multiple indicators in survey research: The concept "sense of political efficacy." Political Methodology, 1(2), 1-43.

Barber, J.D. (1972). The presidential character. Englewood Cliffs, NJ: Prentice-Hall.

Barber, M.J., Canes-Wrone, B., \& Thrower, S. (2017). Ideologically sophisticateddonors: Which candidates do individual contributors finance? American Journal of Political Science, 61, 271-288. DOI: 10.1111/ajps.12275

Baur, J.E., Ellen III, B.P., Buckley, M.R., Ferris, G.R., Allison, T.H., McKenny, A.F., \& Short, J.C. (2016). More than one way to articulate a vision: A configurations approach to leader charismatic rhetoric and influence. The Leadership Quarterly, 27(1), 156-171.

Berggren, N., Jordahl, H., \& Poutvaara, P. (2010). The looks of a winner: Beauty and electoral success. Journal of Public Economics, 94(1-2), 8-15.

Best, H. (2011). Does personality matter in politics? Personality factors as determinants of recruitment and policy preferences. Comparative Sociology, 10, 928-948. doi:10.1163/156913311X607638

Bing, M.N., Davidson, H.K., Minor, I., Novicevic, M.M., \& Frink, D.D. (2011). The prediction of task and contextual performance by political skill: A meta-analysis and moderator test. Journal of Vocational Behavior, 79(2), 563-577. doi: 10.1016/j.jvb.2011.02.006

Bjarnegård, E., \& Kenny, M. (2015). Revealing the "secret garden": The informal dimensions of political recruitment. Politics \& Gender, 11(4), 748-753.

Blass, F.R., Brouer, R.L., Perrewé, P.L. \& Ferris, G.R., (2007). Politics understanding and networking ability as a function of mentoring: The roles of gender and race. Journal of Leadership \& Organizational Studies, 14(2), 93-105.

Blickle, G., Ferris, G. R., Munyon, T. P., Momm, T., Zettler, I., Schneider, P. B., \& Buckley, M. R. (2011). A multi- source, multi- study investigation of job performance prediction by political skill. Applied Psychology, 60(3), 449-474.

Blickle, G., John, J., Ferris, G. R., Momm, T., Liu, Y., Haag, R., ... \& Oerder, K. (2012). Fit of political skill to the work context: A two- study investigation. Applied Psychology, 61(2), 295-322. 
Blickle, G., Oerder, K., \& Summers, J.K. (2010). The impact of political skill on career success of employees' representatives. Journal of Vocational Behavior, 77(3), 383390. doi: 10.1016/j.jvb.2010.05.007

Blickle, G., Schneider, P. B., Liu, Y., \& Ferris, G. R. (2011). A predictive investigation of reputation as mediator of the political- skill/career- success relationship 1. Journal of Applied Social Psychology, 41(12), 3026-3048.

Blickle, G., Witzki, A.H., \& Schneider, P.B., (2009). Mentoring support and power: A threeyear predictive field study on protégé networking and career success. Journal of Vocational Behavior, 74(2), 181-189. doi: 10.1016/j.jvb.2008.12.00

Bock, J., Byrd-Craven, J., \& Burkley, M., (2017). The role of sexism in voting in the 2016 presidential election. Personality and Individual Differences, 119(1), 189-193. doi: 10.1016/j.paid.2017.07.026

Cain, B., Ferejohn, J., \& Fiorina, M. (2013). The personal vote: Constituency Service and electoral independence. Harvard University Press. https://doi.org/10.4159/harvard.9780674493285

Cannella, A.A., \& Shen, W. (2001). So close and yet so far: Promotion versus exit for CEO heirs apparent. Academy of Management Journal, 44(2), 252-270. doi: $10.2307 / 3069454$

Campbell, R., \& Cowley, P. (2014). What voters want: Reactions to candidate characteristics in a survey experiment. Political Studies, 62, 745-765. doi: 10.1111/1467-9248.12048

Campbell, A., Gurin, G. \& Miller, W.E. (1954). The voter decides. Oxford, England: Row, Peterson, and Co.

Caprara, G.V., Barbaranelli, C., Consiglio, C., Picconi, L., \& Zimbardo, P.G. (2003). Personalities of politicians and voters: Unique and synergistic relationships. Journal of Personality and Social Psychology, 84, 849-856. doi:10.1037/0022- 3514.84.4.849

Caprara, G.V., Francescato, D., Mebane, M., Sorace, R., \& Vecchione, M. (2010). Personality foundations of ideological divide: A comparison of women members of Parliament and women voters in Italy. Political Psychology, 31, 739-762.

Caprara, G.V., \& Silvester, J. (2018). The personality attributes of political elites. In H. Best \& J. Higley (Eds.), The Palgrave handbook of political elites (pp. 467-488). London: Palgrave Macmillan. doi: 10.1057/978-1-137-51904-7

Caprara, G.V., \& Zimbardo, P.G. (2004). Personalizing politics: a congruency model of political preference. American Psychologist, 59(7), 581-594. 
Chang, C.H., Ferris, D.L., Johnson, R.E., Rosen, C.C., \& Tan, J.A. (2012). Core selfevaluations: A review and evaluation of the literature. Journal of Management, 38(1), $81-128$

Chen, G., Gully, S. M., \& Eden, D. (2001). Validation of a new general self-efficacy scale. Organizational Research Methods, 4, 62-83.

Childs, S. (2015). The good parliament. Bristol: ERSC/University of Bristol.

Clarke, H.D., Sanders, D., Stewart, M.C., \& Whitely, P. (2009). Performance, politics and the British voter. Cambridge: Cambridge University Press.

Cohen, A., Vigoda, E., \& Samorly, A. (2001). Analysis of the mediating effect of personalpsychological variables on the relationship between socioeconomic status and political participation: A structural equations framework. Political Psychology, 22(4), 727-757. doi: 10.1111/0162-895X.00260

Condon, M., \& Holleque, M. (2013). Entering politics: General self- efficacy and voting behavior among young people. Political Psychology, 34(2), 167-181. doi: 10.1111/pops. 12019

Conway, B.A., Kenski, K., \& Wang, D. (2015). The rise of Twitter in the political campaign: Searching for intermedia agenda-setting effects in the presidential primary. Journal of Computer-Mediated Communication, 20(4), 363-380.

Cortina, J.M., \& Landis, R.S. (2009). When small effect sizes tell a big story, and when large effect sizes don't. In C.E. Lance \& R.J. Vandenberg (Eds.), Statistical and methodological myths and urban legends: Doctrine, verity and fable in the organizational and social sciences (pp. 287-308), New York: Routledge.

Costantini, E., \& Craik, K.H. (1980). Personality and politicians: California party leaders, 1960-1976. Journal of Personality and Social Psychology, 38, 641-661. doi:10.1037/0022-3514.38.4.641

Cowley, P., \& Campbell, R. (2011, September). Designing the perfect politician: exploring desirable candidate characteristics using hypothetical biographies and survey experiments. In Elections, Public Opinions and Parties (EPOP) conference, University of Exeter (pp. 9-11).

Craig, S.C., Niemi, R.G., \& Silver, G.E. (1990). Political efficacy and trust: A report on the NES pilot study items. Political Behavior, 12(3), 289-314.

Day, D.V., \& Sin, H.P. (2011). Longitudinal tests of an integrative model of leader development: Charting and understanding developmental trajectories. The Leadership Quarterly, 22(3), 545-560.

This article is protected by copyright. All rights reserved 
Dawes, R.A., \& Bacot, A.H. (1998). Electoral careers and incumbency advantage in the U.S. House of Representatives. Legislative Studies Quarterly, 23(4), 575-583. DOI: $10.2307 / 440241$

Deluga, R.J. (2001). American presidential Machiavellianism: Implications for charismatic leadership and rated performance. The Leadership Quarterly, 12(3), 339-363. doi: 10.1016/S1048-9843(01)00082-0

Dempsey, N. (2017). Marginal seats. London: House of Commons Library, retrieved from http://researchbriefings.files.parliament.uk/documents/CBP-8067/CBP- 8067.pdf

Denver, D. Carman, C., \& Johns, R (2012). Elections and voters in Britain. London: Macmillan International.

De Vries, M.F.K. (1988). The dark side of CEO succession. Management Review, 77(8), 2328.

Dietl, E., Rule, N., \& Blickle, G. (2018). Core self-evaluations mediate the association between leaders' facial appearance and their professional success: Adults' and children's perceptions. The Leadership Quarterly, 29(4), 476-488.

Dietrich, B.J., Lasley, S., Mondak, J.J., Remmel, M.L., \& Turner, J. (2012). Personality and legislative politics: The Big Five trait dimensions among U.S. state legislators. Political Psychology, 33, 195-210. doi:10.1111/j.1467- 9221.2012.00870.x

Electoral Commission (2019) UK Parliamentary general election in Great Britain. https://www.electoralcommission.org.uk/i-am-a/candidate-or-agent/ukparliamentary-general-election-great-britain Accessed 15 June 2019

Empson, L. (2017). Leading professionals: Power, politics and prima donnas. Oxford: Oxford University Press.

Ewen, C., Wihler, A., Blickle, G., Oerder, K., Ellen III, B.P., Douglas, C. \& Ferris, G.R., (2013). Further specification of the leader political skill-leadership effectiveness relationships: Transformational and transactional leader behavior as mediators. The Leadership Quarterly, 24(4), pp.516-533. doi: 10.1016/j.leaqua.2013.03.006

Fair, R. (2009). Presidential and congressional vote-share equations. American Journal of Political Science, 53, 55-72.

Farber, M. L. (1952). The college student as laboratory animal. American Psychologist, 7(3), 102-102. doi: 10.1037/h0059045

Ferris, G.R., Ellen III, B.P., McAllister, C.P., \& Maher, L.P. (2019). Reorganizing politics research: A review of the literature and identification of future research directions. 
Annual Review of Organizational Psychology and Organizational Behavior, 6, 299323.

Ferris, G.R., Hochwarter, W.A., Douglas, C., Blass, R., Kolodinsky, R.W., \& Treadway, D.C. (2002). Social influence processes in organizations and human resources systems. In Ferris, G.R. \& Martocchio, J.J. (Eds.), Research in personnel and human resources management (Vol. 21, pp. 65-127). Oxford, UK: JAI Press/Elsevier Science.

Ferris, G.R., Perrewé, P.L., Ellen, B.P., McAllister, C.P., \& Treadway, D.C. (2020). Political skill at work: How to influence, motivate, and win support. Boston: Nicholas Brealey Publishing.

Ferris, G.R., Treadway, D.C., Brouer, R.L. \& Munyon, T.P. (2012). Political skill in the organizational sciences. In Ferris, G.R \& Treadway, D.C. (Eds.), Politics in organizations: Theory and research considerations (pp. 487-528). New York: Routledge/Taylor and Francis.

Ferris, G.R., Treadway, D.C., Kolodinsky, R.W., Hochwarter, W.A., Kacmar, C.J., Douglas, C., \& Frink, D.D. (2005). Development and validation of the political skill inventory. Journal of Management, 31(1), 126-152. doi: 10.1177/0149206304271386

Ferris, G.R., Treadway, D.C., Perrewé, P.L., Brouer, R.L., Douglas, C. \& Lux, S. (2007). Political skill in organizations. Journal of Management, 33(3), 290-320. doi: $10.1177 / 0149206307300813$

Fieldhouse, E., Fisher, J., \& Cutts, D. (2019). Popularity equilibrium: Testing a general theory of local campaign effectiveness. Accepted for publication - in Party Politics

Finkel, S.E., (1985). Reciprocal effects of participation and political efficacy: A panel analysis. American Journal of Political Science, 29(4), 891-913. doi: $10.2307 / 2111186$

Fisher, G., \& Aguinis, H. (2017). Using theory elaboration to make theoretical advancements. Organizational Research Methods, 20(3), 438-464.

Fisher, J., Cutts, D., \& Fieldhouse, E. (2011). The electoral effectiveness of constituency campaigning in the 2010 British general election: the 'triumph' of Labour? Electoral Studies, 30(4), 816-828.

Fisher, J. \& Denver, D. (2008). From foot-slogging to call centres and direct mail: A framework for analysing the development of district-level campaigning, European Journal of Political Research, 47(6), 794-826.

Fisher, J. \& Denver, D. (2009). Evaluating the electoral effects of traditional and modern 
modes of constituency campaigning in Britain 1992-2005. Parliamentary Affairs, 62(2), 196-210.

Fisher, J., Johnston, R., Cutts, D., Pattie, C., \& Fieldhouse, E. (2014). You get what you (don't) pay for: The impact of volunteer labour and candidate spending at the 2010 British General Election. Parliamentary Affairs, 67(4), 804-824. https://doi.org/10.1093/pa/gst006

Frieder, R.E., Ferris, G.R., Perrewé, P.L., Wihler, A., \& Brooks, C.D. (2019). Extending the meta-theoretical framework of social/political influence to leadership: Political skill effects on situational appraisals, responses, and evaluations by others. Personnel Psychology, 72(4), 543-569.

Gaines, B. J. (1998). The impersonal vote? Constituency service and incumbency advantage in British elections, 1950-92. Legislative Studies Quarterly, 167-195.

Gerber, A., \& Green, D.P. (2000). The effects of canvassing, telephone calls and direct mail on voter turnout: A field experiment. American Political Science Review, 94(3), 653663. doi: $10.2307 / 2585837$

Gerber, A.S., Huber, G.A., Doherty, D., \& Dowling, C.M. (2011). The Big Five personality traits in the political arena. Annual Review of Political Science, 14, 265-287.

Gist, M., \& Mitchell, T.R. (1992). Self-efficacy: A theoretical analysis of its determinants and malleability. Academy of Management Review, 17, 183-211. doi:10.2307/258770

Glad, B. (2002). Political leadership: Some methodological considerations. In L.O. Valenty \& O. Feldman (Eds.), Political leadership for the new century: Personality and behavior among American leaders (pp. 9-24). Westport, CT: Praeger.

Greaves, M., Zibarras, L.D. \& Stride, C., (2013). Using the theory of planned behavior to explore environmental behavioral intentions in the workplace. Journal of Environmental Psychology, 34, 109-120. doi: 10.1016/j.jenvp.2013.02.003

Greene, K. F. (2020). Campaign effects and the elusive swing voter in modern machine politics. Comparative Political Studies, doi: 0010414020919919.

Greenstein, F. I. (2004). The presidential difference: Leadership style from FDR to George W. Bush. Princeton, NJ: Princeton University Press.

Grosser, T.J., Obstfeld, D., Choi, E.W., Woehler, M., Lopez-Kidwell, V., Labianca, G., \& Borgatti, S.P. (2018). A sociopolitical perspective on employee innovativeness and job performance: The role of political skill and network structure. Organization Science, 29(4), 612-632. 
Hanania, R. (2017). The personalities of politicians: A big five survey of American legislators. Personality and Individual Differences, 108, 164-167.

Hannah, S.T., Avolio, B.J., Luthans, F., \& Harms, P.D. (2008). Leadership efficacy: Review and future directions. The Leadership Quarterly, 19, 669-692. doi:10.1016/j.leaqua.2008.09.007

Harakeh, Z., Scholte, R.H., Vermulst, A.A., de Vries, H. \& Engels, R.C., (2004). Parental factors and adolescents' smoking behavior: An extension of the theory of planned behavior. Preventive Medicine, 39(5), 951-961.

Helgason, A.F., \& Merola, V. (2017). Employment insecurity, incumbent partisanship, and voting behavior in comparative perspective. Comparative Political Studies, 50(11), 1489-1523.

Highhouse, S., \& Gillespie, J.Z. (2009). Do samples really matter that much? In C.E. Lance \& R.J. Vandenberg (Eds.), Statistical and methodological myths and urban legends: Doctrine, verity and fable in the organizational and social sciences (pp. 247-265). New York: Routledge.

Hu, L.T., \& Bentler, P.M. (1999). Cut-off criteria for fit indexes in covariance structure analysis: Conventional criteria versus new alternatives. Structural Equation Modeling: A Multidisciplinary Journal, 6(1), 1-55. doi:10.1080/10705519909540118

Huber, P.J. (1967). The behavior of maximum likelihood estimates under nonstandard conditions. In Proceedings of the Fifth Berkeley Symposium on Mathematical Statistics and Probability (pp. 221-233). Berkeley, CA: University of California Press: Berkeley.

Jacquart, P., \& Antonakis, J. (2015). When does charisma matter for top-level leaders? Effect of attributional ambiguity. Academy of Management Journal, 58(4), 1051- 1074.

Jawahar, I.M., Meurs, J.A., Ferris, G.R. \& Hochwarter, W.A. (2008). Self-efficacy and political skill as comparative predictors of task and contextual performance: A twostudy constructive replication. Human Performance, 21(2), 138-157. doi: $10.1080 / 08959280801917685$

Jimmieson, N.L., Peach, M. \& White, K.M., (2008). Utilizing the theory of planned behavior to inform change management: An investigation of employee intentions to support organizational change. The Journal of Applied Behavioral Science, 44(2), 237-262. doi: 10.1177/0021886307312773

Johnston, R., \& Pattie, C. (2006). Candidate quality and the impact of campaign expenditure: A British example. Journal of Elections, Public Opinion and Parties, 16(3), 283-294.

This article is protected by copyright. All rights reserved 
Joly, J.K., Hofmans, J., \& Loewen, P. (2018). Personality and party ideology among politicians. A closer look at political elites from Canada and Belgium. Frontiers in Psychology, 9, 552.

Jost, J.T., \& Sidanius, J. (2004). Political psychology. New York, NY: Psychology Press.

Judge, T.A., Locke, E.A., Durham, C.C., \& Kluger, A.N. (1998). Dispositional effects on job and life satisfaction: The role of core evaluations. Journal of Applied Psychology, 83(1), 17-34

Karp, J.A., \& Banducci, S.A. (2007). Party mobilization and political participation in new and old democracies. Party Politics, 13, 217-234. doi:10.1017/S0007123408000161

Karp, J.A., \& Banducci, S.A. (2008). Political efficacy and participation in twenty-seen democracies: How electoral systems shape political behaviour. British Journal of Political Science, 38, 311-334. doi:10.1017/S0007123408000161

Karpowitz, C.F., Monson, J.Q., \& Preece, J.R. (2017) How to Elect More Women: Gender and Candidate Success in a Field Experiment. American Journal of Political Science, 61(4), 927-943.

Kimura, T. (2015). A review of political skill: Current research trend and directions for future research. International Journal of Management Reviews, 17(3), 312-332.

Klingler, J. D., Hollibaugh, G. E., \& Ramey, A. J. (2019). What I like about you: Legislator personality and legislator approval. Political Behavior, 41(2), 499-525.

Kolodinsky, R. W., Treadway, D. C., \& Ferris, G. R. (2007). Political skill and influence effectiveness: Testing portions of an expanded Ferris and Judge (1991) model. Human Relations, 60(12), 1747-1777.

Koop, R. \& Bittner, A. (2011). Parachuted into Parliament: Candidate nomination, appointed candidates, and legislative roles in Canada. Journal of Elections, Public Opinion \& Parties, 21(4), 431-452. DOI: 10.1080/17457289.2011.609297

Kraiger, K., Ford, J.K., \& Salas, E. (1993). Application of cognitive, skill-based, and affective theories of learning outcomes to new methods of training evaluation. Journal of Applied Psychology, 78, 311-328. doi:10.1037/0021-9010.78.2.311

Krebs, T. B. (2001). Political experience and fundraising in city council elections. Social Science Quarterly, 82(3), 536-551. https://doi.org/10.1111/0038-4941.00041

Lamprinakou, C. (2015). The 'age' of the new parliament. Parliamentary Candidates UK, Retrieved from http://parliamentarycandidates.org/news/the-age-of-the-newparliament/

Lester, P. B., Hannah, S. T., Harms, P. D., Vogelgesang, G. R., \& Avolio, B. J. (2011). 
Mentoring impact on leader efficacy development: A field experiment. Academy of Management Learning \& Education, 10(3), 409-429.

Lovenduski, J. (2005) Feminizing politics. Cambridge: Polity Press,

Madsen, D. (1987). Political self-efficacy tested. American Political Science Review, 81(2), 571-581.

Maisel, L.S., \& Stone W.J. (1997). Determinants of candidate emergence in U. S. house elections: An exploratory study. Legislative Studies Quarterly, 22, 79-96.

Mathieu, J.E., Martineau, J.W., \& Tannenbaum, S.I. (1993). Individual and situational influences on the development of self-efficacy: Implications for training effectiveness. Personnel Psychology, 46, 125-147.

McAllister, C.P., Ellen, B.P., III. \& Ferris, G.R. (2018). Social influence opportunity recognition, evaluation, and capitalization: Increased theoretical specification through political skill's dimensional dynamics. Journal of Management, 44(5), 1926-1952. doi: $10.1177 / 0149206316633747$

Mensmann, M., Frese, M., Campos, F., Goldstein, M., Iacovone, L., Johnson, H., \& McKenzie, D. (2018, July). Closing the gender gap-personal initiative training and female business performance. In Academy of Management Proceedings (Vol. 2018, No. 1, p. 10669). Briarcliff Manor, NY: Academy of Management.

Mintzberg, H. (1983). Power in and around organizations. Englewood Cliffs, NJ: PrenticeHall.

Mondak, J.J. (1995). Competence, integrity, and the electoral success of congressional incumbents. The Journal of Politics, 57(4), 1043-1069.

Mondak, J.J. (2010). Personality and the foundations of political behavior. New York: Cambridge University Press.

Mondak, J.J., \& Halperin, K.D. (2008). A framework for the study of personality and political behavior. British Journal of Political Science, 38, 335-362. doi:10.1017/S0007123408000173

Mondak, J.J., Hibbing, M.V., Canache, D., Seligson, M.A., \& Anderson, M.R. (2010). Personality and civic engagement: An integrative framework for the study of trait effects on political behavior. American Political Science Review, 104, 85-110. doi:10.1017/S0003055409990359

Mondak, J.J., \& Huckfeldt, R. (2006). The accessibility and utility of candidate character in electoral decision making. Electoral Studies, 25(1), 20-34. doi: 10.1016/j.electstud.2005.02.006 
Morris, M.G., Venkatesh, V. \& Ackerman, P.L., (2005). Gender and age differences in employee decisions about new technology: An extension to the theory of planned behavior. IEEE Transactions on Engineering Management, 52(1), 69-84.

Munyon, T.P., Summers, J.K., Thompson, K.M., \& Ferris, G.R. (2015). Political skill and work outcomes: A theoretical extension, meta-analytic investigation, and agenda for the future. Personnel Psychology, 68(1), 143-184. doi: 10.1111/peps.12066

Murray, R. (2014). Quotas for men: Reframing gender quotas as a means of improving representation for all. American Political Science Review, 108(3), 520-32.

Nai, A. (2019). Disagreeable narcissists, extroverted psychopaths, and elections: a new dataset to measure the personality of candidates worldwide. European Political Science, 18(2), 309-334.

Nai, A., \& Maier, J. (2018). Perceived personality and campaign style of Hillary Clinton and Donald Trump. Personality and Individual Differences, 121(1), 80- 83.

Newman, D.A., (2009). Missing data techniques and low response rates. In C.E. Lance \& R.J. Vandenberg (Eds), Statistical and methodological myths and urban legends: Doctrine, verity and fable in the organizational and social sciences (pp. 7-35). London: Routledge.

Norris, P. (2004). Electoral engineering: Voting rules and political behavior. Cambridge University Press.

Norris, P. (2010). May 6th 2010 British General Election Constituency Results Release 5.0. Available from https://www.pippanorris.com/data

Norris, P., Carty, R. K., Erickson, L., Lovenduski, J., \& Simms, M. (1990). Party selectorates in Australia, Britain and Canada: prolegomena for research in the 1990s. Journal of Commonwealth \& Comparative Politics, 28(2), 219-245.

Norton, T.A., Parker, S.L., Zacher, H., \& Ashkanasy, N.M., (2015). Employee green behavior: A theoretical framework, multilevel review, and future research agenda. Organization \& Environment, 28(1), 103-125. doi: 10.1177/1086026615575773

Oerder, K., Blickle, G., \& Summers, J.K., (2014). How work context and age shape political skill. Journal of Managerial Psychology, 29(5), pp.582-599. doi: 10.1108/JMP-012013-0004

[dataset] Office for National Statistics (2010). Annual population survey. Available from https://www.nomisweb.co.uk/articles/873.aspx

This article is protected by copyright. All rights reserved 
Olivola, C.Y., \& Todorov, A. (2010). Elected in 100 milliseconds: Appearance-based trait inferences and voting. Journal of Nonverbal Behavior, 34(2), 83-110. doi: 10.1007/s10919-009-0082-1

Pattie, C.J., Hartman, T.K., \& Johnston, R. (2019). A close-run thing? Accounting for changing overall turnout in U.K. General Elections. Journal of Representative Democracy, 55 (1), 101-116. doi.org/10.1080/00344893.2018.1555676

Pattie, C.J., Johnston, R.J., \& Fieldhouse, E.A. (1995). Winning the local vote: The effectiveness of constituency campaign spending in Great Britain, 1983-1992. American Political Science Review,89(4), 969-983. http://www.jstor.org/stable/2082521?origin=JSTOR-pdf

Perrewé, P.L., \& Nelson, D.L., (2004). Gender and career success: The facilitative role of political skill. Organizational Dynamics, 33(4), pp.366-378. doi: 10.1016/j.orgdyn.2004.09.004

Pfeffer, J. (1981). Power in organizations. Boston: Pitman.

Podsakoff, P.M., MacKenzie, S.B., \& Podsakoff, N.P. (2012). Sources of method bias in social science research and recommendations on how to control it. Annual Review of Psychology, 63, 539-569. doi: 10.1146/annurev-psych-120710-100452

Ragins, B.R., \& Cotton, J.L. (1999). Mentor functions and outcomes: A comparison of men and women in formal and informal mentoring relationships. Journal of Applied Psychology, 84(4), .529-550. doi: 10.1037/0021-9010.84.4.529

Ramey, A.J., Klingler, J.D., \& Hollibaugh, G.E. (2016). Measuring elite personality using speech. political science research and methods. Advance online publication. doi: 10.1017/psrm.2016.12

Richardson, H.A., Simmering, M.J., \& Sturman, M.C. (2009). A tale of three perspectives: Examining post hoc statistical techniques for detection and correction of common method variance. Organizational Research Methods, 12(4), 762-800.

Rice, M.G., Remmell, M.L., \& Mondak, J.J. (2020). Personality on the hill: Expert evaluations of U.S. senators' psychological traits. Political Research Quarterly, 1-14. https://doi.org/10.1177/1065912920928587

Rodgers, W.M., Conner, M., \& Murray, T.C., (2008). Distinguishing among perceived control, perceived difficulty, and self- efficacy as determinants of intentions and behaviours. British Journal of Social Psychology, 47(4), 607-630. doi: 10.1348/014466607X248903

This article is protected by copyright. All rights reserved 
Rubenzer, S.J., Faschingbauer, T.R., \& Ones, D.S. (2000). Assessing the U.S. presidents using the Revised NEO Personality Inventory. Assessment, 7, 403-420.

Rudolph, T.J., Gangl, A., \& Stevens, D. (2000). The effects of efficacy and emotions on campaign involvement. The Journal of Politics, 62(4), 1189-1197.

Schermelleh-Engel, K., Moosbrugger, H., \& Müller, H. (2003). Evaluating the fit of structural equation models: Tests of significance and descriptive goodness-of-fit measures. Methods of Psychological Research Online, 8(2), 23-74.

Schumacher, G., \& Zettler, I. (2019). House of cards or west wing? Self-reported HEXACO traits of Danish politicians. Personality and Individual Differences, 141, 173-181.

Sharma, S., Mukherjee, S., Kumar, A., \& Dillon, W. R. (2005). A simulation study to investigate the use of cut-off values for assessing model fit in covariance structure models. Journal of Business Research, 58(7), 935-943

Sheafer, T. (2008). Charismatic communication skill, media legitimacy, and electoral success. Journal of Political Marketing, 7(1), 1-24. DOI: $10.1080 / 15377850802063983$

Sheafer, T., \& Tzionit, S. (2006). Media-political skills, candidate selection methods and electoral success. Journal of Legislative Studies, 12(2), 179-197. DOI: $10.1080 / 13572330600739447$

Shugart, M.S., Valdini, M.E., \& Suominen, E. (2005). Looking for locals: Voter information demands and personal vote-earning attributes of legislators under proportional representation. American Journal of Political Science, 49, 437-449.

Sieweke, J. \& Santoni, S. (2020). Natural experiments in leadership research: An introduction, review and guidelines. The Leadership Quarterly, 31, online at: https://doi.org/10.1016/j.leaqua.2019.101338

Silvester, J. (2008). The good, the bad and the ugly: Politics and politicians at work. International Review of Industrial and Organizational Psychology, 23, 107-148.

Silvester J. (2012). Recruiting politicians: Introducing competency-based approval processes for prospective parliamentary candidates. In A. Weinberg (Ed.), The psychology of political leadership. Cambridge: Cambridge University Press.

Silvester, J. \& Dykes, C. (2007). Selecting political candidates: A longitudinal study of assessment centre performance and political success in the 2005 U.K. general election. Journal of Occupational and Organizational Psychology, 80(1), 11-25. doi: 10.1348/096317906X156287

This article is protected by copyright. All rights reserved 
Silvester, J., Wyatt, M., \& Randall, R. (2014). Politician personality, Machiavellianism, and political skill as predictors of performance ratings in political roles. Journal of Occupational and Organizational Psychology, 87(2), 258-279. doi: 10.1111/joop. 12038

Simonton, D.K. (1988). Presidential style: Personality, biography, and performance. Personality Processes and Individual Differences, 55, 928-936. doi:10.1037/00223514.55.6.928

Simonton, D.K. (1998). Political leadership: Part 1 - world heads of state. The Leadership Quarterly, 9, 239-242.

Simonton, D.K., (2006). Presidential IQ, openness, intellectual brilliance, and leadership: Estimates and correlations for 42 U.S. chief executives. Political Psychology, 27(4), .511-526. doi: 10.1111/j.1467-9221.2006.00524.x

Stern, I., \& Westphal, J. D. (2010). Stealthy footsteps to the boardroom: Executives' backgrounds, sophisticated interpersonal influence behavior, and board appointments. Administrative Science Quarterly, 55(2), 278-319. doi: 10.2189/asqu.2010.55.2.278

Stevens, C.K., \& Gist, M.E. (1997). Effects of self-efficacy and goal orientation training on negotiation skill maintenance: What are the mechanisms? Personnel Psychology, 50, 955-978. https://doi.org/10.1111/j.1744-6570.1997.tb01490.x

Stevens, B.A., Islam, M.M., de Geus, R., Goldberg, J., McAndrews, J.R., MierkeZatwarnicki, A., Loewen, P.J., \& Rubenson, D. (2019). Local candidate effects in Canadian Elections. Canadian Journal of Political Science, 52(1), 83-96.

Tavits, M. (2010). Effects of local ties on electoral success and parliamentary behaviour: The case of Estonia. Party Politics, 16(2), 215-235.

Tetlock,P.E. (1984). Cognitive style and political belief systems in the British House of Commons. Journal of Personality and Social Psychology, 46(2), 365-375. doi $=10.1037 \% 2 \mathrm{~F} 0022-3514.46 .2 .365$

Todorov, A., Mandisodza, A.N., Goren, A., \& Hall, C.C. (2005). Inferences of competence from faces predict election outcomes. Science, 308(5728), 1623- 1626.

Tocher, N., Oswald, S.L., Shook, C.L. \& Adams, G., (2012). Entrepreneur political skill and new venture performance: Extending the social competence perspective. Entrepreneurship \& Regional Development, 24(5-6), 283-305. doi: $10.1080 / 08985626.2010 .535856$ 
Treadway, D.C., Hochwarter, W.A., Kacmar, C.J., \& Ferris, G.R. (2005). Political will, political skill and political behavior. Journal of Organizational Behavior, 26(3), 229245. doi: $10.1002 /$ job.310

van Knippenberg, D., van Knippenberg, B., De Cremer, D., \& Hogg, M.A. (2004). Leadership, self, and identity: A review and research agenda. The Leadership Quarterly, 15, 825-856. doi:10.1016/j.leaqua.2004.09.002

Vecchione, M., \& Caprara, G. V. (2009). Personality determinants of political participation: The contribution of traits and self-efficacy beliefs. Personality and Individual Differences, 46, 487-492.

Visser, B.A., Book, A.S., \& Volk, A.A. (2017). Is Hillary dishonest and Donald narcissistic? A HEXACO analysis of the presidential candidates' public personas. Personality and Individual Differences, 106, 281-286.

Walker, M., Jiang, F., Vetter, T., \& Sczesny, S. (2011). Universals and cultural differences in forming personality trait judgments from faces. Social Psychological and Personality Science, 2(6), 609-617.

Webb, T.L., \& Sheeran, P., (2006). Does changing behavioral intentions engender behavior change? A meta-analysis of the experimental evidence. Psychological Bulletin, 132(2), 249-268

Westaby, J.D. (2005). Behavioral reasoning theory: Identifying new linkages underlying intentions and behavior. Organizational Behavior and Human Decision Processes, 98(2), 97-120. doi: 10.1016/j.obhdp.2005.07.003

White, H. (1982), Maximum likelihood estimation of mis-specified models, Econometrica, 50, 1-25. doi: $10.2307 / 1912526$

Whitely, P., \& Seyd, P. (1994). Local party campaigning and voting behaviour in Britain. Journal of Politics, 56, 242-251. doi: 10.2307/2132356

Williams, L. J., \& O'Boyle Jr, E. H. (2008). Measurement models for linking latent variables and indicators: A review of human resource management research using parcels. Human Resource Management Review, 18(4), 233-242.

Williams, L.J., Hartman, N., \& Cavazotte, F. (2010). Method variance and marker variables: A review and comprehensive CFA marker technique. Organizational Research Methods, 13(3), 477-514. doi: 10.1177/1094428110366036

Winter, D.G. (1987). Leader appeal, leader performance, and the motive profile of leaders and followers: A study of American presidents and elections. Journal of Personality and Social Psychology, 50, 196-202. doi:10.1037/0022- 3514.52.1.196

This article is protected by copyright. All rights reserved 
Winter, D.G. (1998). A motivational analysis of the Clinton first term and the 1996 presidential campaign. The Leadership Quarterly, 9(3), 367-376. doi: 10.1016/S10489843(98)90036-4

Wood, R.E., \& Bandura, A. (1989). Impact of conceptions of ability on self-regulatory mechanisms and complex decision making. Journal of Personality and Social Psychology, 56, 407-415.

Wyatt, M., \& Silvester, J. (2018). Do voters get it right? A test of the ascription-actuality trait theory of leadership with political elites. The Leadership Quarterly, 29(5), 609-621.

Zettler, I., \& Lang, J. W. (2015). Employees' political skill and job performance: An inverted u- shaped relation? Applied Psychology, 64(3), 541-577. 


\section{Table 1}

\section{Correlations and Descriptive Statistics}

\begin{tabular}{|c|c|c|c|c|c|c|c|c|c|c|c|c|c|c|}
\hline Variables & & $M$ & $S D$ & 1 & 2 & 3 & 4 & 5 & 6 & 7 & 8 & 9 & 10 & 11 \\
\hline 1 & Gender $^{\mathrm{a}}$ & - & - & - & & & & & & & & & & \\
\hline 2 & Age & 45.73 & 12.16 & .07 & - & & & & & & & & & \\
\hline 3 & Prior campaign experience ${ }^{b}$ & .90 & 1.17 & .03 & $.40 * *$ & - & & & & & & & & \\
\hline 4 & Incumbency $^{\mathrm{c}}$ & .21 & .40 & -.01 & $.20 * *$ & $.48^{* *}$ & - & & & & & & & \\
\hline 5 & Facial appearance $^{\mathrm{d}}$ & 3.66 & .42 & $.29 * *$ & .05 & -.01 & -.03 & - & & & & & & \\
\hline 6 & Seat ${ }^{\mathrm{e}}$ & 3.72 & .72 & $-.18 * *$ & .04 & $-.18 * *$ & -.09 & -.14 & - & & & & & \\
\hline 7 & Economic context $^{\mathrm{f}}$ & 71.23 & 6.05 & .09 & .03 & .02 & .07 & .13 & -.01 & - & & & & \\
\hline 8 & Prior electoral performance ${ }^{\mathrm{g}}$ & 20.58 & 8.11 & $.15^{*}$ & .10 & $.15^{*}$ & .11 & .12 & $-.66 * *$ & $.21 * *$ & & & & \\
\hline 9 & Political skill $^{\mathrm{h}}$ & 3.80 & .50 & $.27 * *$ & .00 & -.12 & -.12 & -.01 & -.06 & .13 & .10 & - & & \\
\hline 10 & Campaign efficacy $^{\mathrm{i}}$ & 3.65 & .51 & $.15^{*}$ & .04 & -.03 & -.06 & .05 & $-.21 * *$ & .10 & $.17 *$ & $.61 * *$ & - & \\
\hline 11 & Intentions $^{\mathrm{j}}$ & 2.12 & .62 & .13 & .14 & .11 & .02 & .12 & $-.45 * *$ & $.21 * *$ & $.50 * *$ & $.23 * *$ & $.26^{*}$ & - \\
\hline 12 & Electoral performance ${ }^{\mathrm{k}}$ & 21.84 & 7.93 & $.14^{*}$ & .10 & .13 & .14 & .12 & $-.63 * *$ & $.27 * *$ & $.88^{* *}$ & .06 & $.17^{*}$ & $.55^{* *}$ \\
\hline
\end{tabular}

$* p<.01, * p<05, \dagger p<.10$

${ }^{\mathrm{a}} 0=$ male, $1=$ female ${ }^{\mathrm{b}}$ Number of times stood for election, ${ }^{\mathrm{c}} 0=$ no, $1=$ yes, ${ }^{\mathrm{d}} 1=$ strongly disagree, $5=$ strongly agree, ${ }^{\mathrm{e}} 1=$ most winnable, $4=$ least winnable, ${ }^{\mathrm{f}} \%$ people in work in constituency, gPercentage of votes in the 2005 election, ${ }^{\mathrm{h}} 1=$ strongly disagree, $5=$ strongly agree, ${ }^{\mathrm{i}} 1$-not at all confident, $10=$ totally confident, ${ }^{\mathrm{j}} 1=\mathrm{low}$ intentions, $4=$ high intentions, ${ }^{k}$ Percentage of votes in the 2010 election

$N=201$ using MLMV estimator, based on observed variables

This article is protected by copyright. All rights reserved 


\section{Table 2}

CFA Model Comparisons

\begin{tabular}{cccccccc}
\hline Model & AIC & BIC & Chi-square & $p$-value & Chi-Sq Diff & RMSEA & CFI/TLI \\
\hline $\begin{array}{c}\text { 3-factor } \\
\text { 2-factor }\end{array}$ & 4956.73 & 5075.66 & $45.90(\mathrm{df}=41)$ & .28 & - & .02 & $.99 / .99$ \\
$\begin{array}{c}\text { (PS\&CE, I) } \\
\text { 2-factor }\end{array}$ & 5089.69 & 5202.00 & $182.85(\mathrm{df}=43)$ & $<.001$ & $136.95(2 ; \mathrm{p}<.001)$ & .13 & $.84 / .79$ \\
$\begin{array}{c}\text { (CE\&I, PS) } \\
\text { 2-factor }\end{array}$ & 4986.29 & 5098.60 & $79.45(\mathrm{df}=43)$ & $<.001$ & $33.55(2 ; \mathrm{p}<.001)$ & .07 & $.96 / .95$ \\
$\begin{array}{c}\text { (PS\&I, CE) } \\
\text { 1-factor }\end{array}$ & 5168.76 & 5281.07 & $261.92(\mathrm{df}=43)$ & $<.001$ & $216.02(2 ; \mathrm{p}<.001)$ & .16 & $.75 / .68$ \\
\hline
\end{tabular}

This article is protected by copyright. All rights reserved 


\section{Table 3}

\section{Indirect Effects}

\begin{tabular}{lccc}
\hline Indirect Effect Paths & \multicolumn{3}{c}{ Electoral Performance } \\
\hline & $\mathrm{b}$ & $\mathrm{SE}$ & $\beta$ \\
\hline Hypothesized model (PS $\rightarrow \mathrm{CE} \rightarrow \mathrm{I} \rightarrow$ Electoral performance) & & & $.05^{* *}$ \\
$\quad$ From Political skill to Electoral performance & $.78^{* *}$ & .23 & $.25^{* *}$ \\
$\quad$ From Political skill to Intentions & $.32^{* *}$ & .06 & $.12^{* *}$ \\
From Campaign efficacy to Electoral performance & $.55^{* *}$ & .16 &
\end{tabular}

Alternative model $1(\mathrm{CE} \rightarrow \mathrm{PS} \rightarrow \mathrm{I} \rightarrow$ Electoral performance)

From Campaign efficacy to Electoral performance

Alternative model 2 (PS and $\mathrm{CE} \rightarrow \mathrm{I} \rightarrow$ Electoral performance)

From Political skill to performance

$\begin{array}{lll}-.06 & .26 & -.00 \\ .63^{* *} & .19 & .14 * *\end{array}$

$.63 * *$ 


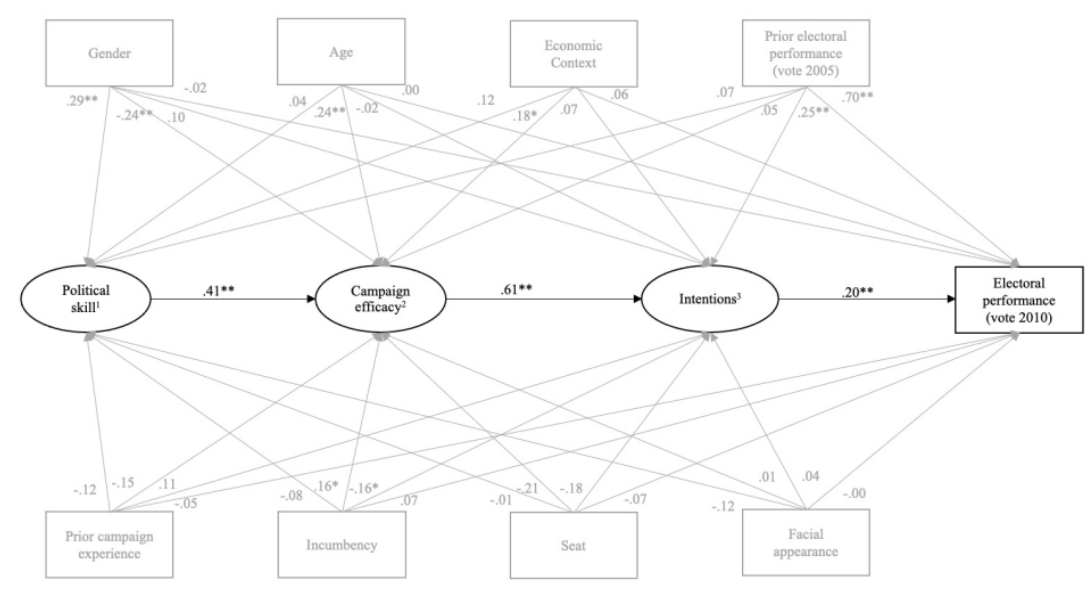

apps_12292_f1.jpg

This article is protected by copyright. All rights reserved 